\title{
Taoista nézőpontok a nyelvértelmezésben és értékelméletben II.
}

\author{
Vajon kinek szánhatták a taoisták müveiket?
}

\subsection{Laozi 老子a szavak nélküli tanításról (buyan 不言) és a nem- cselekvésről (wuwei 無為) mint a dao 道 követéséről}

Amint a tanulmány első részében láttuk, a taoizmus két fő müvére, a Laozire, illetve a Zhuangzire is jellemző az a probléma, hogy szövegeik fordításakor és értelmezésekor az európai filozófiai kategóriáknak megfeleltetett terminológia átfogalmazása oda vezethet, hogy félreérthető szövegekkel találkozik az olvasó. Ugyanakkor arra is fel kell hívni a figyelmet, hogy mivel a Laozit minden valószínűség szerint különböző személyek által lejegyzett mondásokból állították össze valamikor az i. e. 3. században, így terminológiailag sem a mü egésze, sem annak egyes versezetei, passzusai nem feltétlenül koherensek, $\mathrm{s}$ így a ránk maradt mü szövege az egyes terminusokat nem mindig következetesen alkalmazza. ${ }^{1}$

A Hadakozó Fejedelemségek (Zhanguo 戰國) kora igencsak viharos idöszaka a kínai ókor történetének. Nagyon úgy tünik, hogy a Laozi, mint mü, az egyik legjobb „megértője” és reagáló kritikája ennek a „zavaros” kornak. ${ }^{2}$ A dao taoista jelentése alapvetően más, mint a konfuciánus értelmezésé, más, mert az a központi 'hely', amelyet tulajdonítanak neki, felülírja a konfuciánusok egész beállítódását. Annak ellenére, hogy az egymással szembehelyezkedő irányzatok termonológiai tekintetben sokszor kölcsönviszonyban állnak, az előző időszakokban legitimált jelentések egy más értelmezési térbe helyezése eredményezheti egy saját tanítás megalapozását, $\mathrm{s}$ a dao taoista átértelmezése ezt a szerepet tölti be. ${ }^{3}$

\footnotetext{
Kósa 2013a: 167. Ivanhoe 2003: XVII.

Takó 2011:195.
} 
A dao eredeti használatában „út”, útirány”, „menni”, ,járni”, „úton lenni”, „utat mutatni”, „vezetni”, jelentésű terminus már korán, éppen utóbbi jelentéseinél fogva, fontossá válik a bölcseleti szövegekben, például ,az ég útja” (tiandao 天道) vagy ,,a régi királyok útja”(xian wang zhi dao 先王之道) elnevezésekben.A taoisták emelik középponti szerepkörbe.

A Laozi 老子 vagy Daodejing 道德經 a taoizmus alapmüve, legismertebb klasszikusa tömör, paradoxonokkal teli, képszerü vízió a daóról, az „Út”-ról, a világot mozgató alapvető, mindeneken túli, maradandó, és az efemer világban érzékekkel fel nem fogható „Nagy Egységről”. A dao minden jelenség gyökere (ben 本), minden dolog egységes forrása (yuan 元), melyben minden látszólagos szembenállás, minden párosság (yin 陰 és yang 陽, fent és lent, szép és rút, élet és halál) feloldódik, mivel mindezeknek a kettőségeken túlmutató eredete. Egyben maga az az út is, amelyen a dolgok (wu 物) természetes módon, saját maguktól spontán (ziran 自然) 'járnak'. ${ }^{5}$ A de 德 azt a ,potenciát”, ,erôt”, illetve „,hatást”, ,teljes valót”, , ,autoritást” jelenti, ${ }^{6}$ amely által egyes dolgok, beleértve az embert, részesülnek a daoból, ez a mérték, amely mindenkit azzá tesz, ami; a de a dao 'megjelenése', alkalmazása az ,égalattiban” (tianxia 天下). Amennyiben a de tökéletesen kiteljesedik, az egyes ember számára a dao legteljesebb jelenlétét eredményezi. ${ }^{7}$

Laozi felveti a konvencionális tudás vagy a nyelv használhatóságának kritikáját. Ez szorosan összefügg a nyelv kérdésével, mivel míg a „nevek” (ming 名) a Daodejing szerint nyilvánvalóan nyelvi háttérbe beágyazottak, $\mathrm{s}$ emberi megkülönböztető ítéletalkotás hozza létre azokat, s így minden megnevezés magában hordozza saját ,párját” is, addig a dao, amely már nincs alávetve a nyelvben is megjelenő kettősségeknek, párosságoknak, természetes módon nyelvileg nem is fogalmazható meg. Aki tehát e kettősségek egyikéhez sem ragaszkodik, képes alkalmazkodni a világban megjelenő mozgásukhoz, az maga is a kimondhatatlan és leírhatatlan dao irányában lép túl rajtuk. ${ }^{8}$

Fontos tudnunk, hogy a konfuciuszi „egyenes nevek” (zhengming 正名) kérdéskörének problémája csak a „száz iskola” (baijia 百家) időszakában kerül elő és lesz komoly viták tárgya, az egész kínai bölcselet nyelv- és hatalom-

\footnotetext{
Schuessler 1987: 115, Schuessler 2007: 207.

Kósa 2013a: 167.

Schuessler 1987: 117, Schuessler 2007: 208.

Kósa 2013a: 171.

Kósa 2013a: 171, 175.
} 
értelmezésének egyik alapjaként. ${ }^{9}$ A Laozi még nem közvetlenül a konfuciuszi 'felmutatás' reflektálása felől közelít a „nevek” és a nyelv, „beszéd” (yan 言) nehézségeinek értelmezéséhez, de az általa tárgyalt 'nevek megfelelése - nemmegfelelése' nyilvánvalóan érinti a zhengming teóriájából adódó kérdéseket. Az igény tehát az, hogy a nevek (ming) „lefedjék” a valóságot (shi 實), mert ez a lefedés egyben a valóság regulálása is. A cél azonos, csupán megvalósításának a módja - ez az, amiben a különböző gondolkodók és iskolák eltérnek egymástól a kínai bölcselet története során. Amin ők vitatkoznak, az a zhengming hogyanja és mikéntje, illetve vannak olyanok, akik ennek paradoxon jellegére világítanak rá. ${ }^{10}$ Ezzel összefüggésben, ha a propozíció, vagyis a „tétel kimondása” fogalmát vizsgáljuk, megállapítható, hogy az európai filozófiával szemben a kínai bölcseletben az nem kapott olyan nagy szerepet. Ennek oka abban lehet, hogy - bár voltak, akik próbálkoztak a „mondat fogalmának meghatározásával" - azért nem vált szembetűnővé és maradéktalanul megoldandóvá ez a kérdés, mondja Harbsmeier, mert szintaktikailag maga a mondat nem kap akkora jelentőséget (mert inkább 'mondás', tehetnénk hozzá), mint az indoeurópai nyelvek esetében. ${ }^{11}$

Laozi a megnevezhető dolgoktól mintegy eltekintve, elsősorban arról beszél, ami „névvel nem illethető”. ${ }^{12}$ Nézzük meg, azok közül a legfontosabb 'meghatározások', pontosabban kényszerü mégis névvel illetések közül, amelyekkel a Laozi szövege a daora 'utal', az egyik mostani vizsgálódási szempontunkból alapvetőt, amely szerint a dao megnevezhetetlen. „Nem tudom a valódi nevét (ming), kisebbik nevén ( $z i$ 字) szólítva nevezem daonak." ${ }^{13} \mathrm{~A}$ dao tehát megnevezhetetlen (feiming 非名), beszéddel nem kifejezhető (buyan). ,Így aztán a bölcs ember a nem-cselekvés (wuwei 無為) tevékenységével (wei為) él, s a szavak nélküli (buyan 不言) tanítást valósítja meg." ${ }^{14}$ „Aki tud, az nem beszél, aki pedig beszél, az nem tud." ${ }^{15}$ Maga a buyan, a „szavak nélküli”, pontosabban „,beszéd nélküli” tanítás paradoxont hordoz. Ezt a paradoxont a kínai írásbeliségen belül is felismerik. Kína egyik legnagyobb költője, a Tang-kor kiválósága, Bo Juyi 白居易 így ír „Laozi olvasása közben”

\footnotetext{
Várnai 2010: 15-16, 18-19, 23-24, Várnai 2011: 20-24.

10 Várnai 2013: 456.

11 Harbsmeier 1991: 140-143.

12 Feng 2003: 130-131.

13 Laozi XXV; Tökei 2005b: 25, Várnai 2013: 397-398.

14 Laozi II; Tökei 2005b: 17.

15 Laozi LVI; Tökei 2005b: 36.
} 
(Du Laozi 讀老子) címü versében: „Ki nem bölcs: beszél. /Ki bölcs: csendben él./ Laozi bölcs, s ír ötezer szót - mér?"16 (言者不如知者默, 此語吾 聞於 老君。/ 若道老君是知者, 緣何自著五千文)

A dao ebben a mivoltában, nincsen-neve (wuming 無名) 'státuszában' az eredet, kezdet (shi 始) maga. Ha névvel bír (youming 有名), megszületnek a dolgok (wanwu 萬物). ${ }^{17}$ Minden névadás egyfajta meghatározás, elhatárolás, különválasztás, megkülönböztetés (bian 辨) más dolgoktól. Mivel azonban a dao minden levés alapja és bennfoglalója, ezért nincs elválaszthatósága. Csak a „tízezer levőnek” (wanwu 萬物) van elválaszthatósága. A gondolat egy további konnotációja, amely más passzusokban bomlik ki, hogy a nyelv használata csak az emberi értelem határain belül felfogható egyes dolgok ( $w u$ 物) vonatkozásában lehetséges, a megnevezhetetlen dao azonban meghaladja azt, mivel felfoghatatlan. ${ }^{18}$

A dao „maga” tehát névtelen, név nélküli. A megnevezés, amelyet használunk rá, ugyanis a „dolgok világához” tartozik, így nem is lehet azonos a minden dolog (wanwu) „mögött rejlővel”, annak ellenére sem, hogy az megnevezve maga is „,egy dolog”. Márpedig a név (ming) 'azonosítási vonatkozásban' kellene legyen a dologgal $(w u)$. A Laozi egyik középponti passzusában ez a gondolat ekként fogalmozódik meg: ,a dao[nak] amely elhagyja szájunkat... nincs íze!”"19 Szó szerint: ,,ami a szájon keresztül kimegy”, ez kulcshelye a mondatnak. Itt szerepel a „vendég” ( $k e$ 客) terminus, ami egyáltalán nem véletlen. Ez a terminus Zhuangzi egyik alaptézisében is megjelenik: „a név [名]... a valóság (實) vendége". ${ }^{20}$

A szövegegészből látható, megjelenik egy olyan összefüggés észrevétele is, amely a névvel ellátott 'jelenségek', a „dolgok” mögött rejlö, egy névvel meg nem fogható „valót”, „dolgot” (shi 實; $w u$ 物) jelez, pontosabban arra utal, tudván tudva, hogy a névvel való utalás nem ér el „hozzá”. Mert bár eredete közös vele, nem azonos azzal, és nem ragadható meg általa. ${ }^{21}$ Mindezzel egybecsengően tekinti helytelennek (buzheng 不正), majdhogynem elvetendőnek Laozi a névadást. Aminek neve van, az már nem jelenti a dolgot, hanem csupán a nevet. Söt, mint azt több passzus kimondja, azt sem helyesen.

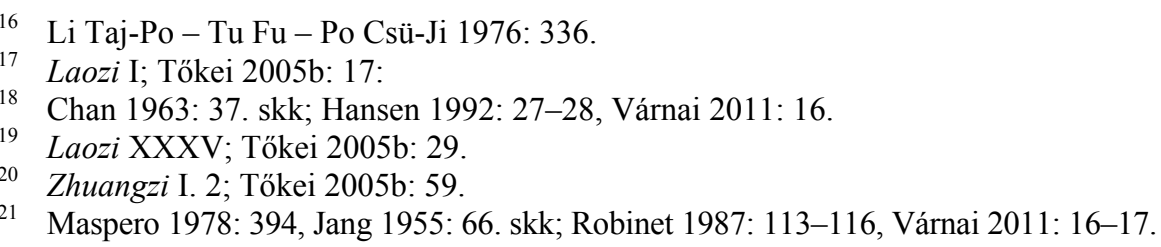


S az ilyen név a dolgot sem tudja pontosan megragadni. Szinte lehetetlen feladatra vállalkozunk tehát, ha a daot akarjuk megnevezni. A feloldás talán abban van, hogyha a dao maga megragadhatatlan is, az a praxis, amely az úton vezet, a wuwei 無為, és annak körüljárása illethető szavakkal. ${ }^{22}$

„Bármennyi azonban a szó, az mind kimerül.. ${ }^{, 23}$ Vajon akkor hogyan értelmezhetjük a „neveket”, hogyan érthetjük meg a gondolatmenetet, ha a nyelvi realizálás nem bizonyul elégségesnek. Maga a Laozi szövege reflektál a befogadhatatlanságára, de e reflektálás paradoxonhordozó. „Az én szavaimat [yan 言 „,beszédemet” - V.A.] nagyon könnyü megérteni, és nagyon könnyű megvalósítani is őket. Az égalattiban mégsem tudja megérteni senki, mégsem tudja megvalósítani senki (a tanításomat). Pedig szavaimnak van őse (alapja), tetteimnek van ura (vezető elve). Éppen ezt nem tudják megérteni az emberek, $\mathrm{s}$ ezért nem ismernek... ${ }^{24}$ A nyelvi realizálás elégtelensége mögött újra ott van a dao megragadhatatlanságának nyugtalanító volta, amit a Laozi szerzője (vagy szerzői) nyilvánvalóságában belát(nak), ám ambivalens tudomásulvétellel fogad(nak). „A dao rejtett és nincsen neve. ${ }^{, 25}$ A megnevezhetetlenség ellenére a Laoziben három „utaló” név illeti a daot: ,yi, xi,wei”. „Nézem, és nem látom, ezért a neve: észrevehetetlen ( $y i$ 夷). Hallgatom, és nem hallom, ezért a neve: illanó ( $x i$ 希). Megragadom, de nem tudom megfogni, ezért a neve: parányi (wei 微). ${ }^{26}$ Helmuth Glasenapp értelmezése: ,megismerhetetlen, meghatározhatatlan, felfoghatatlan". Feng Youlannak olyan megfogalmazási kísérlete van, amelyik körülírást alkalmaz: „ami által minden keletkezik”, „mindent átható rend”, ,,a nem-cselekvés (wuwei 無為) révén ható”. ${ }^{27}$ „Ha valaki nézi, nincs mit meglátnia; ha valaki hallgatja; nincs mit meghallania. Aki azonban használja (yong 用), az nem tudja kimeríteni." ${ }^{28}$

Egy másik lehetséges nyelvi realizálási esély, amikor a megnevezést utalásként értelmezve, mintegy a névhasználatban rejlő 'kódolással' mégis 'jelentéssel bíróvá', pontosabban megnevezhetővé tesszük a rámutató ( $z h i$ 指, eredetileg tkp. ,ujj”) nevet. „Nem tudom a valódi nevét (ming), kisebbik nevén szólítva ( $z i$ 字) nevezem daonak. Erőszakoltan nevet adva neki, azt mondom,

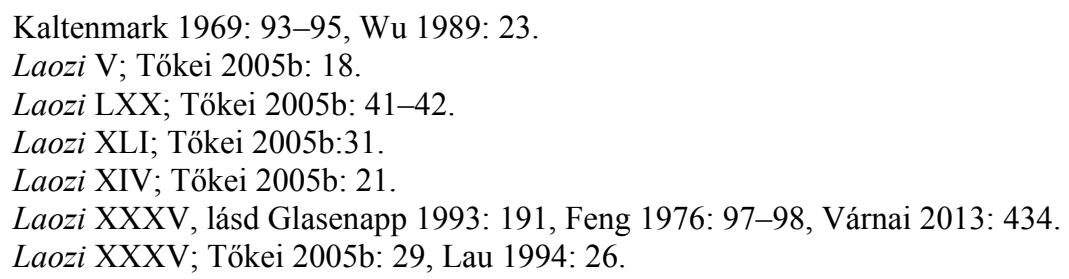


hogy „nagy”, a „nagyot” pedig „tovahaladónak” is mondhatom, a „tovahaladót” „messzeségbe tünőnek” végül ,a messzeségbe tünőt” ,visszatérőnek”. Ezért nagy a dao[.]" ${ }^{\prime 29}$ Itt válik nyomatékossá, hogy mindenféle nyelvi 'meghatározás' elégtelen, hiszen mindig található egy másik nyelvi 'jel', amellyel kifejezhető az, amire a ráutalás történik, így állandó mozgásban van ,'az, ami van', a kérdéseinkben, amikor kérdezünk, és a válaszainkban, amikor válaszolunk." ${ }^{30}$

Neves kutatók egy része azon a véleményen van, hogy a guodiani Taiyi shengshui 太一生水 egyfajta kommentárja a Laozi-nek. ${ }^{31}$ Úgy vélik a Taiyi a daoval azonosítható, bár elismerik, hogy a Han-kor előtt nem mindig volt jelentéskölcsönösség, hanem a Taiyi csak utalt a daora. Véleményük szerint a tai 太 és a $d a$ 大 írásjegyeket gyakran nem megkülönböztetetten használták, így az ,[e]röszakoltan nevet adva neki, azt mondom, hogy nagy” közvetlenül a Taiyi-ra utalhat. Ezt látják megerősítve a Lüshi chunqiuban 呂氏春秋, amelyben hasonlóképpen találják 'jellemezni': „A dao ... megnevezhetetlen, korlátozottan az mondható, nagy egy." ${ }^{32}$ Úgy gondolom, ez nem igazolható tézis, ugyanis ,[a] dao szülte az Egyet, az Egy szülte a kettőt, a kettő szülte a hármat, és a három szülte az összes létezőket (wanwu 萬物) [valójában: „tízezer levőt” V.A.]”33 állítás az azonosítást lehetetlenné teszi, hiszen azt a Laozi-ben sehol nem találjuk, hogy a dao önmagát szülte volna, sőt azt találjuk, hogy „nem tudom, hogy szülötte-e valakinek”. ${ }^{34}$ Julien megjegyzése - miszerint a Laozi XXV. versében a kommentátorok előszeretettel használják ezt a variánst: ,you yi wu [...] 有一物 ,existit unum ens [...]”, de ez igen problémás, mert egy olyan interpretációt ad, amely konstruált, nem a szöveg eredeti mondandójához tartozó ${ }^{35}$-, szintén ezt tűnik igazolni.

Vizsgáljuk meg ezek után egy kicsit alaposabban, miben van a taoisták dao terminusának alapvető eltérése a konfuciánus értelmezéstől. A Lunyuben 論語 van egy igen fontos metafora, amelyben Konfuciusz azt mondja, hogy az útonjáráshoz „ki kell lépni az ajtón”. „Hogy van” - kérdezi - „hogy senki sem jár az úton?" ${ }^{36}$ A Laoziben erre a kérdésre igen frappáns, tagadó választ ka-

\footnotetext{
Laozi XXV; Tőkei 2005b: 25, Várnai 2011: 17.

Platón: Phaidón 75 d. PÖM I. 1052.

Allan-Williams 2000: 167.

Allan-Williams 2000: 163, 168.

Laozi XLII; Tőkei 2005b: 31.

Laozi IV; Tökei 2005b:18.

Julien 1842: 173.

Lunyu VI. 15; Tökei 2005b: 83.
} 
punk. „A bölcs ki sem lép az ajtón”, mégis az úton jár. ${ }^{37}$ A metaforikus kérdés és válasz mögött egymást kizáró, ellentétes álláspontok feszülnek. Konfuciusz az utat (dao) a ,nemes emberek” (junzi 君子) számára tartja fenn. Vagyis az úton-járás nála a kiválasztottak egy keskeny ösvényen való haladása. Ezzel szemben a Laozi dao-felfogása az égalatti minden lényét útonjáróként gondolja el, és ebből válik egyértelmüvé, hogy maga a dao a levés egy olyan egysége, melyben a „tízezer dolog / levő” (wanwu 萬物) mindegyike a maga (zi 自) útját járva, mégis a közös úton (gong dao 公道) jár. ${ }^{38}$

Mind a Laozi-ben, mind a Zhuangzi-ben metaforikus passzusok szólnak a „faragatlan fa” ( $p u$ 檏) állapotról, amellyel az eredendő létállapotokra, a dolgoknak a daoban való 'leledzésére' utalnak. Ebben az értelemben a faragás, a dao „müködésébe” (de 德) való beavatkozás. A taoisták éppen ezt tartják problematikusnak a konfucianizmusban. A mesterséges beavatkozás (wei 為) a wen (müveltség 文) segítségével, a rend megteremtésének igényével felborítja a dolgok „levésének” eredeti összhangját. „Amikor elkezdődött a faragás, megjelentek a nevek. S minthogy a nevek már megjelentek, velük meg lehet ismerni a határokat is. Aki tudja, hol kell megállnia, elkerülheti a veszélyeket."39 A nevek az eszközei annak, hogy eligazodjunk a világban, hogy megteremtsünk egy bizonyos rendet, ez azonban a mi rendünk, amely ugyan alapjául szolgál a számtalan lehetséges „faragásnak”, de többé sohasem hozza vissza a „faragatlan fa” állapotot.

A dao egy fontos vonását a Laozi egyik kulcsterminusa hordozza: ,a dao a maga olyansága (ziran 自然) törvénye”, vagy pontosabban: „a dao a maga olyanságát követi". ${ }^{40}$ Ebben a híres laozi-i passzusban, a dao azt 'követi', ami a dao maga, vagyis a dao nem követ semmi mást, és minden más őt/azt követi. Ebből adódik egy figyelemreméltó összefüggés. A Laoziben az - a „Tavaszok és Öszök” (Chunqiu 春秋) korának végén, a „Hadakozó fejedelemségek” (Zhanguo 戰國) időszakában is erősen ható - ősök kultusza és az általa vezérelt szemléletmód [a $l i$ 禮 ,,szertartásrend”], amely meghatározó a konfuciánus erénytan tanítására, alárendelődik annak a tapasztalat határain túli, érzékeinkkel felfoghatatlan keretnek, amely az „Út” és a „tízezer (dolog)” egymásra vonatkozó terminuspárjában jelenik meg. ${ }^{41} \mathrm{~S}$ amennyiben a zi ran

37 Laozi XLVII; Tőkei 2005b: 33.

38 Chen 1989: 37; Schwarz 1990: 43-45, Kaltenmark 1969: 117-119.

39 Laozi XXXII; Tökei 2005b: 28, Duyvendak 1954: 19-21, Schwarz 1990: 134-135.

40 Laozi XXV; (Tökei 2005b: 25) a szerző értelmezése.

41 Roberts 2001:19. 
a dolgoknak erre az eredendően meglévő egységességére-milyenségére mutat rá - hiszen a dolgok „magasága” a dao „magaságából” ered -, azt az 'evidenciát' mondja ki, hogy a dolgok ,sajátmaguk”. S érdemes megjegyezni, hogy ezt az 'evidenciát' a mingjia 名家 neves alakja Gongsun Longzi hasonlóan látja: „A dolgok megőrzik dologiságukat, amely dologgá teszi őket, s nem lépnek túl sajátmagukon: ez a valóság ( $s h i$ 實) ... nem hagynak rést: a helyükön vannak (wei 位)." ${ }^{42}$ Ö azonban nem füzi össze ezt a taoista „misztikával”, hanem megmarad annak belátásán, hogy a „dolgok magasága”, „helyén levése" és névvel való megragadási kísérletük között hiátus marad.

A dao egy másik fontos vonása - mint erre már történt utalás - „, homályossága”, ,rejtettsége” (yin 隱). „A dao maga, mint dolog, homályos és megfoghatatlan. Ó, megfoghatatlan és homályos! [...] benne képek (xiang 象) vannak. Ó, igen, homályos, és megfoghatatlan! [...] benne dolgok vannak. Ó, átáthatatlan és sötét! [...] benne csírák (jing 精) vannak. Ezek a csírák nagyon igazak, benne van az igazság (xin 信 [valójában „hitelesség”, ,,valóban”, ,,megbízható”, „öszinte”, „szavahihető”, „bizonyosság”, illetve egy másik vonatkozásban „kiterjed”, „folytatódás”, „meghosszabbítás”, „kiegyenlítés”43 V.A.]). ${ }^{44}$ Egy pillanatra álljunk meg a xin súlyának megértése kedvéért, amely a Lunyu-ben is kulcsfontosságú szerephez jut, „öszinte-szavahihető" ${ }^{45}$ jelentéstartalommal. A „,virtue of trustworthiness" ${ }^{\circ 6}$ az egyik legfontosabb konfuciánus erény. Mit keres ez a Laoziben? Nem egészen ez a helyzet, nem a Lunyu követelményének parafrázisával van dolgunk.

A „csírákban (jing 精) van az igazság (xin 信 [,hitelesség”,])”. Ez a mondat, funkcionális fontossága mellett, megint a nyelvi értelmezés felől fejthető ki igazán. A csírák (jing 精) kifejezés, egy nagyon fontos - már a korai szövegekben, a „Dalok Könyvében” (Shijing) és a „Változások Könyvében” (Yijing) is szereplö -, a mag, magok kicsírázása kapcsán, a növekedést és átalakulást reprezentáló terminus, amely arra vonatkozik, ami „éltet”, ${ }^{47} \mathrm{~s}$ itt abban a jelentésben van jelen, amelya de 德, vagyis a dao müködéseként hatóerejének kifejlése, és ezáltal a „tízezer dolog” (wanwu 萬物) megjelenése

\footnotetext{
42 Gongsun Longzi VI; Tőkei 2005b: 141, Várnai 2011: 22.

43 Karlgren 1996: 109-110 (384a), Wieger 1965: 600, Schuessler 1987: 685, Schuessler 2007: 539.

44 Laozi XXI; Tökei 2005b: 23-24.

45 Lunyu I. 4,5; Tökei 2005b: 57-58.

46 Kósa 2015:87.

47 Wieger 1965: 584.
} 
eredetére utal. Ez az eredet - mint láttuk - maga, a dao. A dao nem „oka” (causa) a dolgoknak, hanem eredete, kezdete (yuan 元). Abból jönnek ki, és oda térnek vissza, miközben folytonosan benne vannak. Az úton járnak, nem „attól” járnak! Ezt az összefüggést, a szöveg archaikus tömörségén keresztül mutatja az is, hogy kategóriapárként - a Tökei Ferenc által itt helytelenül igazságnak fordított - xin 信 terminus szerepel. Vagyis itt a szöveg kettős mondandót mond. Elsődlegesen azt mondja, hogy a „csírákban” van a dolgok ( $w u$ 物) ,kiterjedése”, vagyis annak eshetősége, hogy vannak (you 有), és „folytatódásuk” lehetősége. Ugyanakkor azt is mondja nekünk, hogy az 'elbeszélo’' szavahihetősége éppen abban van - a tekintetben, hogy „honnan ismerem?”, „honnan tudom?” -, hogy a „,csírák”-ban nyilvánul meg müködésén, hatásán (de) keresztül a dao. Itt a „hitelesség” (xin 信) persze nem a konfuciánus, a szolgálattételre vonatkozó értelemben szerepel, hanem abban a jelentésében, hogy a „megnevezett dao" ugyan nem éri el a daot magát, de a „hiteles, hitelt érdemlő” (,confidence”, ${ }^{\text {, }}$ ) megnevezés által - ez a jing 精 („csírák”) terminus - áttételes, a müködésen (de 德) keresztüli módon ugyan, de mégis „rámutatással” ( $z h i$ 指, „ujj”), 'tart' „magához” a dao-hoz. ${ }^{49}$ Komoly kérdés persze, hogy ,a szavak [yan 言] legyenek megbízhatóak [xin 信]” követelménye,$^{50}$ amelynek igényéröl a Laozi szövege több helyen is beszél (yan 言), például a záró LXXXI. versben (,trustworthy words” 信言 ${ }^{51}$ ), vajon hogyan teljesíthetö.

Kövessük tovább Laozi mondandóját. „A régmúlt időktől mind a mai napig nem is veszett el a neve (ming), hanem minden dolog kezdetének jelölésére [yue 閲 - valójában „,szemlél”, „vizsgál”, „összegzés”, „,megfeleltetés”,52 V.A.] szolgál. Hogy honnan ismerem én minden dolog kezdetét? Éppen általa." ${ }^{, 53}$ Mielőtt értelmezünk, megint nézzük a fordítás egy lehetséges variációját (a három utolsó mondatot). „A régmúlt időktől mind a mai napig nem veszett el a rendeltetése (ming 命), hogy általa buzdítassék az Atyák serege. Honnan tudjuk, hogy így áll a dolog az összes Atyákkal? Ez által., ${ }^{, 4}$ Amire itt fontos felhívni a figyelmet, az az összefüggés, amely a „név”, „megnevezés”, „,́rott

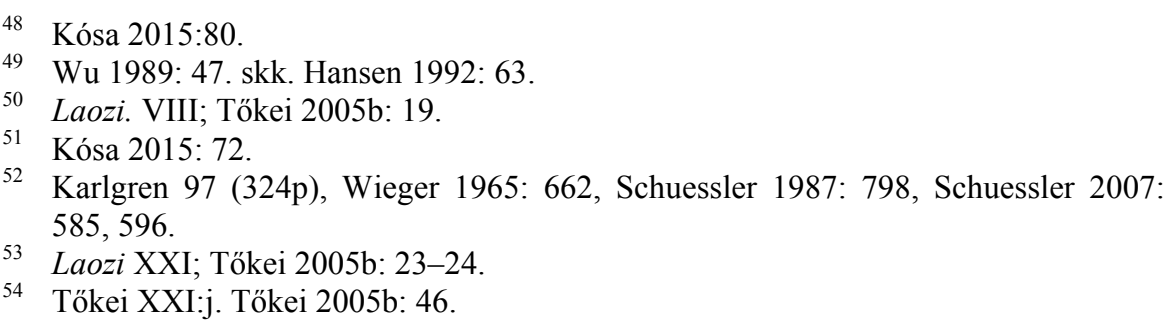


szó”, „hírnév” (ming 名) és a „névadás”, „rendeltetés”, „,sors”, „megbízatás”, „parancs”, „kijelölés”, „,beiktatás”, ,(égi) akarat” (ming 命) ideogrammák eredendően közös vonatkozására utal, mely ekkora már ugyan az írásképben nem olyan nyilvánvaló, de korábban eredetileg fennállt. ${ }^{55} \mathrm{~A}$ kezdetek és az „atyák seregének", vagyis az ősöknek egymásra vonatkozása is majd' nyilvánvaló.

És most valamit a jelentés továbbértelmezéséről. A megismerésben megkülönböztetjük az érzékeket és mentális tevékenységünk által az érzékletet és az érzékeltet. A mindennapi emberi megismerés mindig részek megismerése, mindig körülhatárolás. Ehhez képest a Laozi 'sugalmazása' szerint tényleges megismerésre csak az képes, akiben nincs szétválasztottság, aki nincs elválasztva a daotól, az „egésztöl”, és így megismerése az egység megismerése. Aki az elkülönült, ,névvel illetett” elhatárolt dolgok megismerésével foglalatoskodik, az a képeket (xiang 象 - jelenés, jelenség) érzékeli és ismeri meg, de az ilyen értelem számára a dao, melyben a képek és a dolgok vannak, de amely maga nem kép és nem konkrét dolog, megfoghatatlan. Homályosságán keresztül csak az ragadhatja meg, aki maga is „olyan, akárcsak a homály”,56 (yin 隱 „,rejtett”, , ,elfedett” „rejtőzködés”, ,,alkalmazkodás”, „, ,hajlékonyság”,"57).

Egy igen figyelemreméltó -értelmezési problémát is mutató - gondolata a Laozinek: a bölcs úgy őrzi meg az egységet, hogy átlátja ,,a nem teljes teljessé válik, a görbe egyenessé lesz, az üres teltté lesz. [...] [Éppen] ezért lesz elismert vezető (zhang 長)." ${ }^{98}$ Ezt a szöveghelyet másként is lehet értelmezni, ha lehetséges, hogy más írásjegy volt a szövegben eredetileg, „ezért [...] tartós (chang 常)" ${ }^{59}$ (Ez így összecsengene a Laozi I. első és második mondatával. „A dao 道, amelyet szavakkal ki lehet fejezni nem az örök [chang 常] dao.” [szó szerint: „A dao amelyet daozni lehet [vagy: daozható], nem [a] tartós dao.”] „A név (ming 名),amelyet meg lehet nevezni nem az örök [chang 常] név.” [szó szerint: „A megnevezhető név nem tartós név.”] ${ }^{60}$ Érdemes megjegyezni, hogy Tőkei a XXVII. Jegyzetében megfelelően fordít, míg az I.-ben nem: „örök”! Ennek a problémának a kifejtését a tanulmány első felében

\footnotetext{
55 Karlgren1996: 218-219 (826a-c), 201-202 (762a-b), Huang 1964: 487-488, Ощанин 1959: 313, Karlgren 1962: 47-48.

56 Ян 1950: 147, Waley 1958: 34-35.

57 Karlgren 1996: 123 (449a), Schuessler 1987: 754, Schuessler 2007: 564, 574.

58 Laozi XXII; Tökei 2005b: 24.

59 Tőkei XXII:j., Tőkei 2005b: 46.

60 Laozi I; Tőkei 2005b:17.
} 
tárgyaltam.) A Stanislas Julien által kiadott kötetben, a kínai szövegben chang 常 is szerepel, de Julien mégis így értelmezi: „ezért mások vezetője”. ${ }^{61}$

Mindaz, amit tudásnak nevezünk, megkülönböztetéseken alapszik, amelyet az ember szemszögéből hozunk létre. Ezek a megkülönböztetések, amelyekkel a dolgokat adott voltukban fogjuk fel, valójában a dolgok kölcsönös, egymást feltételezését, és egymás nélküli el nem gondolhatóságát teszik megragadhatóvá számunkra. „Amikor az égalattiban mindenki felismeri a szépről, hogy szép, akkor megjelenik a rút is. Amikor mindenki felismeri a jóról, hogy jó, akkor megjelenik a rossz is."

Az emberi ítéletalkotás hozza létre a „neveket” (ming 名), de minden megnevezés magában hordozza saját „párját” is. Mivel az égalatti (tianxia), az emberi világ, része a folytonos váltakozásoknak, de egyedüli részese e folytonos váltakozások megismerésének, amikor a megnevezéseket újra és újra létrehozza, akkor újra és újra szolgálja és alakítja is ezeket a váltakozásokat. Az emberi ítéletalkotás ezáltal megrontja dao és deösszhangját:

„Mikor a nagy daot pusztulni hagyták, megjelent az emberség (ren 仁) és az igazságosság ( $y i$ 義) [valójában,,méltányosság” - V.A.]. Mikor pedig elkezdődött a bölcselkedés, megjelent a nagy képmutatás. Mikor a hat rokon nem tudott többé békében megférni egymással, megjelent a gyermeki kegyelet (xiao 孝 [valójában: ,gyermeki kötelesség” V.A.]) és a szülöi szeretet ( $c i$ 慈 [valójában: ,atyai kötelesség” - V.A.]). Mióta a fejedelemséget és családjait (guojia 國家) felfordulás borítja homályba, azóta megjelentek a 'hűséges alattvalók'."63

Laozi szerint tehát a világban csak azért léteznek a konfuciánus 'kategorikus' erények, mert az emberek a nevek révén elkezdtek 'sorbarendezni', és ennek megfelelően cselekedni (wei 為), letérve az útról (dao). Mindezek azonban csak az igazi erények (de) pótlékai, ezért az erények (ren 仁) konfuciánus követelményei nem jelentenek megoldást, a megoldás csak a dao-hoz való visszatérés lehet, amelyet magát is a „visszatérőként” (fan 反) nevez meg a Laozi. $^{64}$

A megkülönböztetések (bian 辩) regulatív funkciójával a nevek „,beosztásának", besorolásának révén a nyelv a neveken keresztüli viselkedésirányító

61 Julien 1842. 31-32.

62 Laozi II; Tökei 2005b: 17, Robinet 1987: 97-99.

63 Laozi XVIII; Tökei 2005b: 22-23.

64 Laozi XXV; Tökei 2005b: 25, Várnai 2011: 17, Várnai 2013: 444. 
szerepet kap. ${ }^{65} \mathrm{Az}$ „,egyenes nevek” (zhengming 正名) teóriájának előíró rendszere „a szavak nem-tartós irányítását” adja. Ezt a paradoxont mutatja fel a Laozi, amelyben a taoizmus indulásánál megfogalmazódik a „nevek teóriájának" kontrasztjaként, hogy a nevek nem pusztán megkülönböztetések, hanem eredetükben „oppozíciós karakter-párként” jelennek meg. ${ }^{66}$

„Amikor az égalattiban mindenki felismeri a szépről, hogy szép, akkor megjelenik a rút is. Amikor felismeri a jóról, hogy jó, akkor megjelenik a rossz is. ... lét (you 有) [,,van”, „ott van”, „ez-az”, ,valami”, ,valamije van, bír valamivel”, ,akármi”, ${ }^{67}$ ] és nemlét (wu 無) [,nincs”, „hiány”, „semmi (ami van)"68] egymásból születik, nehéz és könnyü egymást hozza létre, hosszú és rövid egymást alakítja, magas és mély egymásba hajlik, zeneszó és énekhang egymással cseng össze, előbbi és későbbi egymást követi." ${ }^{, 9}$

A $w u$ és you a keletkezések során a daoból születő dolgok ,átmeneti pontja” vagy yin 陰 - yang 陰陽 egymásba átfordulása, amelyet wu és you váltakozásának kölcsönhatása ad meg a még „,nem-levés”, a „valamivé levés” (keletkezés) és a „semmivé válás” (pusztulás) állandó folyamatában. ${ }^{70}$ Emellett a you, mint „bírás” és a wu mint „hiány” egy beleérző attitüdöt mutat fel, mely a nevek és a megkülönböztetés révén a nyelv használatában megjelenik. ${ }^{71}$

A megnevezhetelen, megragadhatatlan dao megnyilvánulása a de 德, az az „erő”, illetve „hatás”, „teljes való”, amely által a „tízezer dolog” részesül a daoból. Ez a megnyilvánulás you 有 és $w u$ 無 váltakozásában 'ölt testet'. A bölcs ember (shengren 聖人) a nem-cselekvés (wuwei 無為) révén valósítja meg a daoba való 'belehelyezkedést'.

„[A] bölcs ember (shengren 聖人) a nem-cselekvés (wuwei 無為) tevékenységével él, s a szavak nélküli (buyan 不言) tanítást valósítja meg." ${ }^{, 72} \mathrm{~A}$ „beszéd nélküliség” (buyan) mondandója, hogy mivel a nevek és következésképpen a beszéd mégsem bizonyulnak azonosnak a tényleges valósággal, nem

\footnotetext{
Hansen 1981: 335.

Hansen 1992: 216, 211.

Schuessler 1987: 769-771, Schuessler 2007: 580.

Schuessler 1987: 646, Schuessler 2007: 517, 518-519.

Laozi II; Tökei 2005b: 17.

Szojka 2007: 122-123.

Hansen 1981: 330.

Laozi II; Tőkei 2005b: 17.
} 
fedik azt le, nem kötik azt át, így általuk nem adható a „valóság” $\left(s h i\right.$ 實 ${ }^{73}$ mikéntjéről szerzett tényleges tudás sem, amely ily módon csupán „intuitív belátással" szerezhető meg. ${ }^{74}$

Ha azt kérdezzük, mi az a tudás, amelyet szavakban nem lehet kifejezni, akkor azt mondhatjuk, hogy ez a „magasabbrendü” bölcs ember (shengren 聖人) „tudása”, amely a $w u$ és a you fogalmával kapcsolatos. A $w u$ 無 azt jelenti: „,nem”, „nincs”; a you: „van”. You az, ami megnyilvánult, és ezért tapasztalható, a $w u$ pedig a lappangó, rejtett, amely nem tapasztalható, vagyis az, ami éppen a „nemvanban tartózkodik”. A yang és yin pár is úgy váltogatják egymást, hogy amikor az egyik megnyilvánult, vagyis you, akkor a másik látens, vagyis $w u$. Ezek a státusok azonban ritmikusan, rendszeresen megcserélődnek. ${ }^{75}$ „Egy yin egy yang, ezt nevezzük dao(nak) ${ }^{976}$ [Yi yin yi yang zhi wei dao一陰一陽之謂道] Henri Maspero fordításában: „A yin és a yang egymásrakövetkezése az, amit daonak hívnak." ${ }^{, 77}$ A Xici-ben a yin és a yang a dao maga, amely nincs „önmagában meghatározva”, csak mint yin és yang ,időbeli összege”. A taoizmusban ez a „szemléletmód” megváltozott, a dao „önmagában való realitásként" jelent meg. ${ }^{78}$ Marcel Granet interpretálásában a yin és a yang, időbeli és térbeli aspektusában egyaránt a dao megnyilvánítása, $\mathrm{s}$ az egymásravonatkozásuk eredménye. ${ }^{79} \mathrm{~A}$ dao a „folytonosság törvénye”, amelynek a „Változás” alá van rendelve - értelmez ettől eltérően Richard Wilhelm. ${ }^{80}$ Derk Bodde a daot „,személytelen ősokként”, „elsődleges mozgatóként" "jellemzi, ${ }^{81}$ hogy a görög filozófia arisztotelészi iniciatíváira asszociálhassunk. Csakhogy az arisztotelészi Első Mozgató bizony az Istenség. Vagyis ajánlatos óvatosabban elemezni.

A helyzet azonban az, hogy a magyarázat nem leegyszerüsíthető. A yang és yin pár ugyanis a wu és you állapotok között inganak, ezért egy adott jelenségre azt mondhatjuk, hogy you és $w u$ egyszersmind. A valódi $w u$ tudása viszont arra vonatkozik, ami a köznapi világban soha nem nyilvánul meg, mégis van, mint „végső dolog” (qiong 窮 „,végső”, „legtávolabbi”), a dao.

\footnotetext{
Karlgren 1996: 113: (398a-c), Schuessler 1987: 545, 546, Schuessler 2007: 564, 574.

Várnai 2011: 17.

Maspero 1971: 63, Lau 1994: 47. skk.,Várnai 2013: 425.

Tökei 2005a. 37.

Maspero 1978: 383.

Maspero 1978: 383-384.

Granet 1934: 126-128.

Wilhelm 1994: 24.

Bodde 1942: 295.
} 
Erre a „végsőre” a you és a $w u$ valósága nem alkalmazható, inkább azt mondhatjuk, se nem wu, se nem you. Ennek megismerését, megértését azonban gátolja az analizáló, illetve spekulatív eljárás müködtetése, amellyel éppen „elhagyjuk” ezt a „végsőt", eltávolodunk a „legtávolabbitól”. ${ }^{82}$ A Laozi szerint csak a valódi $w u$ 無 (,nincs”) tudás birtokában ismerhetjük fel a dolgok a „végső”-ben, a „teljes”-ben (qiong 穹), a daoban meglévő egységét, azt, hogy a „van”-ok (you 有) a „nincs”-ből jönnek. A wu (,nincs”) tudása segítségével látja a bölcs úgy a daot, mint amivel azonos. Ez az egyetlen nagy egész, amelynek bármely helye lehet „közép” (zhong 中), és ebből a középből tekintve érthetjük meg a dolgokat, ezért nincs értelme, és jelentése sincs annak, hogy külső és belső világunkat megkülönböztessük. Erre is utal a már idézett belátás: ,[a] (bölcs) ki sem lép az ajtón, s megismeri az égalattit. Ki sem pillant az ablakon, mégis látja az égi daot." ${ }^{, 83}$

A shengrennek a nagy összhanghoz való eljutása a dao egyfajta intuitív megértését is jelenti. Ez a megértés a yin-yang váltakozásának felismeréséből adódik. A nemtudás-tudás kettősségéből, és egymásravonatkozásából. Hogy mi számít tudásnak az emberi célok és vágyak, a megismerési törekvés határozzák meg. Az „igazi tudás” a wen 文 (műveltség) felől tekintve nemtudás, mivel vágytalan, belehelyezkedő ,ismerete” az egésznek. „A tudást nemtudásnak tartani a legmagasabb fok. A nemtudást tudásnak tartani betegség. Csak aki betegségnek ismeri fel a betegséget, az tud ez által megszabadulni." ${ }^{84}$ Mivel a beszéd csak a wen értelmében vett tudás közlésére alkalmas, melynek hiányosságai nyilvánvalóak, és a daora vonatkozó tudás kifejezhetetlen, ezért a bölcs a szavak nélküli tanítást megvalósítva saját életén keresztül nyilvánítja meg a daot. „Ezért a bölcs ember (shengren 聖人) nem járkál, mégis megismeri $[\ldots]$ nem nézelödik, mégis megnevezi $[\ldots]$ nem tevékenykedik, mégis beteljesíti $[\ldots] . "{ }^{, 85}$

Mivel, mint már láttuk, a nyelvi realizálás során komoly nehézségek merülnek fel, a „bölcs” (shengren) a nem-tudás tudásának átadhatóságával kapcsolatban is bizonyos fenntartásokkal élhet csak. A nem-cselekvés (wuwei 無為) révén a „bölcs” megvalósítja, hogy „minden dolog hat rá, és nem utasítja vissza [...] létrehoz, de nem veszi birtokába; teremt, de nem ragaszkodik. Múvét beteljesíti, de nem él vele. S éppen azért, mert nem él vele, nem is

\footnotetext{
2 Várnai 2013: 425.

83 Laozi XLVII; Tőkei 2005b: 33, Wu 1989: 27, Robinet 1987: 33-36

84 Laozi LXXI; Tőkei 2005b: 42.

85 Laozi XLVII; Tőkei 2005b: 33.
} 
veszítheti el. ${ }^{96}$ A tanításnak ez a belső rejtett kiteljesedése, és az a belátás, hogy a tanítás ezen belső alapvető vonatkozása nem kinyilvánítható, kifejthető, átadható, a Daodejing egyik legfontosabb 'üzenete'. Ez a 'nemlegesség' a „legfontosabbak” taníthatóságára nézve, persze jelen van Konfuciusznál is, csak a Lunyu szerint erre a „nemes embernek” (junzi 君子) törekednie kell, míg a Laozi ezt hiábavalónak tekinti. Laozinél kérdőjeles a „valami végső dologhoz való eljutás" lehetősége és ugyancsak nagy hangsúlyt kap az átadás lehetetlenségének megsejtése, $\mathrm{s}$ a létparadoxon abban áll, hogy mégis megkisérli, hiszen a mü itt van.

A belső tanítást hordozó gondolat, és annak a nevekkel való megfogalmazott kifejezése hordozza a Laozi belső feszültségét. A nem-azonosságnak ez a felismerése a dao és a dao „megnevezhetőségének” (,ming dao” 名道) megkülönböztetésével, szorosan összefügg a taoizmus egész teóriájával és praxisával, ebből adódik a szavak nélküli tanítás álláspontja is. Ez a tanítások egyfajta „zárójelbe helyezését” jelenti, azok ugyanis csak a „nevek világáról” valamint a megnevezett világról mondanak valamit, de a dao maga - metaforikus kifejezéssel élve, „eröszakoltan 'nagyobbik'” „nevén” nem nevezhető meg, ezért - kimondhatatlan. Hiszen ,a dao önmaga olyansága" ${ }^{87}$

Ahhoz, hogy azt a fordulatot világosan lássuk a klasszikus kínai bölcselet nyelvelméleti jellegében, amely a „név” (ming) és a „valóság” (shi) viszonyának rendbetételi igényével jelentkezve az i. e. 4-3. század folyamán olyan elevenné teszi a bölcseleti vitákat (bian 辯), Maspero alapján némi rendszerezéssel kell élnünk a dao „fogalma” átértelmeződése tárgyában. Maspero a dao előfordulásának első fontos állomásaként a jósok iskoláját folytató „metafizikusok" irányzatát vizsgálja. ${ }^{88}$ Ezekben az írásokban a dao a yin és a yang viszonyában 'határozódik', meg. „A yin és yang egymásra következése az, amit daonak hívnak [...]”. „Ami megelózi a formát [xing 形 - „test”, V. A.],

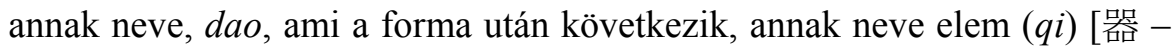
valójában: ,edény”, ,eszköz”, V. A.]." ${ }^{89}$ A xing ,,formának”, illetve a $q i$,elemnek" fordítása igen problematikus, mert újfent a görög alapokon kifejlö európai filozófia kategóriáit implikálja egy más jelentéstartományú szövegbe, Maspero lábjegyzete elég árulkodó: ,azért választottam az „elem” jelentést

\footnotetext{
86 Laozi II; Tökei 2005b: 17, Moritz 1990: 43.

87 Laozi XXV; Tökei 2005b: 25, Schwarz 1990: 17, 21.

88 Maspero 1978: 381-385.

89 Maspero 1978: 383.
} 
mert a qi és a $w a n w u$ 萬物 viszonya hasonlónak tünik számomra a kémiai elemek és lények és tárgyak viszonyához". ${ }^{90}$

A dao és a dolgok között tehát megszakítatlan folytonosság létezik; ez egy olyan átalakulás, amely egymásra következő fázisokban megy végbe, a „testetlen" daotól a ,testet öltő" dolgokig, egy olyan fokozaton keresztül, amelyik látható lesz anélkül, hogy „testi” lenne. „A dolgok a daoból jönnek létre, az átalakulás utolsó fokán, a yin és a yang pedig nem az átalakulást irányító erők, mivel ök a dao maga: valóban a Xici-ben 繫辭 a dao sehol sincsen önmagában „meghatározva”, hanem mindenütt csak a yinnel és yanggal való viszonyában, amelyeknek csupán összege. ${ }^{, 91}$ Maspero kiemeli, hogy „,a taoisták az elsők, akik egy önmagában való realitást alkotván a daoból, ezt a szemléletmódot megváltoztatták. ${ }^{92}$ De a dao a taoisták értelmezésében nem csupán új, „intellektuális státuszt nyert” fogalom lett, hanem beilleszkedett egyfajta misztikus gyakorlatba, ${ }^{93} \mathrm{~s}$ értelme csupán e gyakorlaton keresztül a „tökéletesedés”, a „bölcs emberré” (shengrenné) válás útján világosodhatott meg. Ha azonban ez így van, akkor kérdés, hogy mi lehet a szerepe itt még a ,szónak” (yan, „beszéd”), a verbális tanításnak, és mi módon képes befogni ez a verbális ráirányulás a „megnevezés” (ming 名) „tárgyát”, a „valót” (shi), anélkül, hogy elvétené. Úgy tünik, az ilyen jellegü „mondás” (yan) egyetlen lehetséges formája a paradoxon.

A Laozi ebben az értelemben tulajdonképpen nem más, mint paradoxonok sorozata. Az állítások egy része a daora, mint a világot mozgató-nyugalomban tartó „egységre” vonatkozik, másik részük pedig az emberi szférára, ahol elsősorban a shengrennek a daoval összhangban lévő „müködésére” (de 德) utal. Ezek a kijelentések ,váltakozva” követik egymást, de mindvégig összhangban maradnak, mintegy „párhuzamos síkokat” alkotva egymással. Nézzünk meg néhány fontosabb, megvilágító erejü példát e párhuzamra, bár nyilvánvaló, hogy maga az efféle kiemelés, kategorikus megkülönböztetés nehezen fér össze a taoista szövegek intencióival.

Az igazi dao szavakkal kifejezhetetlen, magában álló. A daoról nem lehet pontos kijelentéseket tenni, a negatív jellegü állítás csupán behatárol egy tartományt, megjelöl egy utat, egyfajta hangoltságot, amelyben közelíteni lehet hozzá. „A dao (道), amelyet [...] ki lehet fejezni, nem az [nem maga a] [...]

\footnotetext{
90 Maspero 1978: 383: 71. j.

91 Maspero 1978: 383-384.

92 Maspero 1978: 384: 72. j.

93 Maspero 1978: 391.
} 
dao"; 94 „Van egy dolog (wu 物) [...] Nem tudom a valódi nevét (ming 名), kisebbik nevén szólítva ( $z i$ 字) nevezem daonak."95 A dao minden dolog kezdete, s müködése áthat minden dolgot. Habár a világ strukturált egész, s a dolgok rendjében különböző fokozatok vannak, a dao nem csupán e hierarchia csúcsán álló, hanem minden mögött és mindenben jelenlévő, bár néha épp hiánya, vagy hiányos müködése révén jelenlévő eleven erö. „Az, aminek nincsen neve, az Ég és Föld kezdete (shi 始). ${ }^{96}$ A dao az egység, a megkülönböztetés-nélküliség. Amíg a dao teljességében megőrizve jelen van, nincs szükség kitüntetett fogalmakra, értékekre, megkülönböztetésre. Minden részleges, pozitív és negatív 'pólusokat' létrehozó különbségtevés a hanyatlás jele. A bölcs, éppen mert maga is „,homály”,97 (yin 隱, ,,rejtett”, „,elfedett”, ,rejtőzködés”, „alkalmazkodás”, ,hajlékonyság"98) átlátja, hogy a dao szilárd és egyedül-bizonyos, egyszerre a ,teljességet” (qiong 窮) jelentő minden, és a homályba vesző semmi. „A dao maga, mint dolog, homályos [yin 隱 ,,rejtett”] és megfoghatatlan.",99

A Laozi szerzője a kezdet kérdése kapcsán a fenti 'megoldásban' gondolkodik: „Az, aminek nincs neve (dao 道) az Ég és Föld kezdete (shi 始)." A paradigmatikus ming 名 az általa kiragadott valóságtöredék egyediségével azonosítható be. Ezért nem nevezhető meg a dao „névvel” (ming 名), csak $z i$ 字 (,adott név” - „kisebbik név”) révén utalva rá. ${ }^{101}$ „A dao szülte az Egyet, az Egy szülte a kettőt, a kettő szülte a hármat, és a három szülte az összes létezőket (wanwu 萬物) [valójában: „tízezer levőt” V.A.]."102 Mint már arról szó volt, a dao a kisebbik név, tehát ez már egy a kezdetet követő státus. Glasenapp ezt kozmológiai spekulációként interpretálja, ahol a dao a világ ősoka, minden lény forrása. Ezzel alapvetően szemben áll Feng Youlan értelmezése, a dao éppen megnevezhetetlenségéböl fakadóan nem lehet egy dolog, hasonlóan a többi dolgokhoz (bár a szövegben kétségtelenül egy helyütt kifejezetten úgy kezdődik a daora való utalás, hogy ,van egy dolog"103 -V.A.). A dao

94 Laozi I;Tőkei 2005b: 17.

95 Laozi XXV; Tökei 2005b: 25, Várnai 2013: 397-398.

96 Laozi I., XLII; Tőkei 2005b: 17, 32.

97 Laozi XX; Tökei 2005b: 23.

98 Karlgren 1996: 123 (449a), Schuessler 1987: 754, Schuessler 2007: 564, 574.

99 Laozi XXI; Tőkei 2005b: 24.

100 Laozi I; Tökei 2005b: 17.

101 Hansen 1992: 84-87, Várnai 2013: 406.

102 Laozi I, XLII; Tökei 2005b: 17, 32.

103 Laozi XXV; Tökei 2005b: 25. 
elsődlegessége, mindenekelötti-valósága formális logikai értelemben veendő, vagyis a dao pozitív jelentése ontológiai és nem kozmogóniai Feng szerint. A dao nem a lineáris időfogalom talajáról értelmezhető keletkezés-keletkeztetés, de a megértés szempontjából vett kezdet kérdésére reflektá1 ${ }^{104}$ - erre Feng joggal hívja fel a figyelmet. Ugyanakkor jól látszik, hogy mindketten azt a sztereotip fogalmi megközelítést erőltetik, mely nyugati gondolkodásmódunk sajátja.

A ,kettő”-ség, a (yin-yang 陰陽) párok a daoból egymást létrehozva keletkeznek. „Az égalattiban, amikor mindenki felismeri a szépről, hogy szép, akkor megjelenik a rút is [...] lét [van] és nemlét [nincs] egymásból születik, nehéz és könnyü egymást hozza létre, hosszú és rövid egymást alakítják, magas és mély egymásba hajlik [...]." ${ }^{105}$ Itt arról van szó, hogy a dolgok yinyang állapota folytonosan egymásba vált át, váltakozik, egy adott státus túlfeszülése párjába válthat át: ,ami nagyon egyenes, hasonlít a görbéhez, aki nagyon ügyes, hasonlít az ügyetlenhez, aki nagyon vitatkozó, hasonlít a dadogóhoz." ${ }^{106}$ Ebben az összefüggésben, a fordításban már fel sem tünik egy olyan túlinterpretáció, amely ezt mondja: „Az ellentétesség (fan 反) a dao mozgása.”107 Csakhogy a fan „visszatérést”, „körkörösséget”, „körbefordultat”, illetve ,szembefordultat” jelent. ${ }^{108}$ A megnyugvás, az állandóság, a gyökérhez való visszatérés maga a daohoz valóvisszatérés, a daonak való megfelelés. A Laozi szerint az egymást váltás ugyan a müködés része, de az „ellenkezőkké” fokozódás valami nemkívánatosnak a jelenléte volna, amelyet wuweijel 無為 és buyannal 不言 kell a helyére tenni. ${ }^{109}$ A fan a „mindenségben” zajló vált[ak]ozások ,alapelvét”, a végletek közötti ciklikus mozgást reprezentálja - mondja Feng Youlan. ${ }^{110}$

A dao megismerhetősége vagy megismerhetetlensége felől másfajta bizonyossággal-bizonytalansággal kell számolnunk. A dao „minden titkok kapuja". ${ }^{111}$ Arról azonban, hogy ez egy nyitott kapu lenne, nem lehetünk bizonyosak. Feng úgy értelmezi ezt, hogy a Laozi elkülöníti a „formák és sajátosságok világán" belüli, illetve azon túl fekvő dolgokat. Az előbbi kategóriába tartozó

104 Glasenapp 1993: 192, Feng 1976: 87, Várnai 2013: 388, 398, 435.

105 Laozi II; Tőkei 2005b:17.

106 Laozi XLV; Tőkei 2005b: 33, Kaltenmark 1969: 27, Chen 1989: 47-48.

107 Laozi XL; Tőkei 2005b: 31, Legge 1971: 83-84.

108 Karlgren 1996: 84-85 (262a-d), Wieger 1965: 592, Schuessler 2007: 250.

109 Várnai 2013: 436.

${ }^{110}$ Feng 1960: 182-183,388-392.

111 Laozi I; Tökei 2005b: 17. 
dolgok a tényleges érzékelhető világ dolgai mind megnevezhetők, míg az utóbbiak közül van, ami megnevezhető, például Ég és Föld (Feng 'nyugatias' értelmezésében az „Univerzum”), de a dao a maga „határtalanságával-határolhatatlanságával” [qiong 窮 „teljes, végső”], osztatlanságával-oszthatatlanságával, már nem jelölhető névvel. ${ }^{112}$ A megnevezés (ming) által válnak a dolgok határolttá, ahogy a megkülönböztetések (bian 辨) kapcsán világossá lesz, és így a megnevezés által jönnek létre a dolgok - „számunkra”! Azért nagyon lényeges ez, mert a gondolkodás és a nyelv megismerésbeli szerepének fontosságát jelzi. A nevek ilyenfajta szerepéről gondolkodás a gondolkodásról gondolkodás. Ebben funkcionálissá válik a nyelv szerepe, még akkor is, ha a Laozi konklúziója a nyelvhasználat-nélküliség (buyan) elönyben részesítése lesz. Ez azzal függ össze, hogy a megnevezhető határa a megismerhető az elgondolható határa is lesz, ami pedig az elhatárolások - megnevezések - révén jön létre. Ami ezen túl van, az a megnevezhetetlen, „kisebbik nevén" nevezve dao. ${ }^{113}$

És végül nézzük a Laozi közösségre vonatkoztatott mondandóját. A daonak a világ rendjét leírni szándékozó aspektusa mellett van valamiféle 'társadalomkritikai' vonatkozása. A Laozi a tökéletes rendhez vezető út fontosabb elveiről és eszközeiröl, illetve ezeknek az uralkodás és kormányzás világában alkalmazandó módszereiről is beszél. A bölcs „nem-cselekvése” (wuwei 無為) nem passzivitást, hanem a dao müködésébe való be-nem-avatkozást jelent, azaz a daoval azonosulni képes bölcs uralkodó nem a saját vágyaiból származó céljait próbálja megvalósítani, hanem engedi, hogy rajta keresztül a dao nyilvánuljon meg a világban. Ez a „nem-cselekvés” az eredendő harmóniába való belehelyezkedést, annak megörzését aképpen viszi végbe, hogy a bölcs, ,a középet megőrizve” aktív cselekedetekkel (wei 為) nem zavarja meg az „Út” spontán múködését. ${ }^{114}$

A bölcs (shengren 聖人) olyan, mint az újszülött, ${ }^{115}$ örzi az eredeti, gyermeki és egyszerü spontaneitás dao-közeliségét, aminek elvesztéséhez vezet, ha a civilizáció külső normarendszere, szertartások és „erények”, tanulás és nevelés révén az égi utat valójában elhagyják. A Laozi a konfuciánus értékeket, mint „szertartásosság” ( $l i$ 禮), „emberség” (ren 仁), „méltányosság”( $y i$ 義), „szülőtisztelet” (xiao 孝) inkább a dao elvesztésének következményeként

112 Laozi XXXII; Tőkei 2005b: 28, Feng 1976: 94-95, Várnai 2013: 437.

113 Waley 1958: 73, Lau 1994: 23-25, Robinet 1987: 47-48, Várnai 2011: 17-18.

114 Kósa 2013a: 171.

115 Laozi XX; Tökei 2005b:23. 
látja, és ezen értékeket, mivel csak konvenciók, elvárások, melyek a hierarchikus hatalmat és intézményeit szolgálják, nem tartja alkalmasaknak arra, hogy ezek mentén egy emberi közösség vagy az egyes ember egy dao által áthatott módon élhessen. ${ }^{116}{ },[\ldots]$ a dao elvesztése után jelenik meg az erény (de), az erény elvesztése után jelenik meg az emberség (ren 仁), az emberség elvesztése után jelenik meg az igazságosság ( $y i$ 義 [valójában „méltányosság V.A.]), [...] elvesztése után jelenik meg a szertartásosság ( $l i$ 禮). ${ }^{117}$ Habár éppen ezek miatt - vagyis amiatt, hogy csak ezen, az emberek számára nyilvánvalónak tűnő követelmények a 'láthatóan' követendőek - a dao követése túllépne rajtuk, ezek miatt tehát a dao megfoghatatlan volta a „közönségeseket” (suren 俗人), akik „ragyognak”, elriasztja, csak a „homályban levő” fogja fel. ${ }^{118}$

A Laozi az ideális uralkodás megvalósításához elkerülendőnek tart minden felesleges, túlzott szabályozást. „A fejedelemséget egyenességgel < szabályokkal> lehet kormányozni [...] [a]z égalattit meghódítani csak a nem-dolgoztatás (wushi 無事 - [tkp. „ügy-nélküliség” - V.A.]) útján lehet." ${ }^{119}$ Az ideális társadalom kifejezetten kicsiny, egymással nem kommunikáló közösségek olyan tagjait jelenti, akik a saját világukat nem hagyják el, a számukra adott körülményekkel tökéletesen elégedettek. „Legyen kicsiny az ország, de kevés a népe. Legyen úgy, hogy birtokoljanak bár tízszeres és százszoros (munkát végző) szerszámokat, de ne használják azokat. Legyen úgy, hogy a nép inkább két halált haljon (otthon), de ne menjen soha messzire. Birtokoljanak bár hajókat és kocsikat, senki se szálljon azokra; birtokoljanak bár páncélokat s fegyvereket, senki se vegye elő azokat."120 Ideális esetben az uralkodó spontán módon hagyja saját magán keresztül a dao ,áthatolását” müködni, ezzel is segítve végső soron, hogy ha a nép az ilyen uralkodót követi, akkor a dao áthatja magukat a kicsiny, önmagukban megelégedett közösségeket. „Aki a fejedelemséget birtokolván az Anyához megy, maradandóságot biztosít." ${ }^{\text {"21 }}$ Ennek az idealizált, archaizáló utópikus képnek nem véletlenül az egyszerüen,

\footnotetext{
116 Kósa 2013a: 172.

117 Laozi XXXVIII; Tökei 2005b: 30.

118 Laozi XX; Tőkei 2005b: 23.

119 Laozi LVII; Tőkei 2005b: 36.

${ }^{120}$ Laozi LXXX; Tőkei 2005b: 44.

${ }^{121}$ Laozi LIX; Tőkei 2005b: 37.
} 
természetes módon élő kisebb közösségek a hordozói, elvetve a hierarchikus hatalmat és intézményeit. ${ }^{122}$

A taoizmus alapmüve, a Laozi radikális szakítás a konfucianizmus és motizmus kormányzási elveivel, elutasító a tevékeny (wei 為) kormányzással szemben, a wuwei 無為 hasznosságát tanítja, a shengren 聖人 csak így kormányoz jól. „,[A] bölcs ember úgy kormányoz jól, hogy [...] [m]egvalósítja a nem-cselekvést és minden a legteljesebb rendben lesz." "23 A Laozi végsőkig vitt kritikai funkciója azzal függ össze, hogy nem hisz az elit civilizatorikus funkcióiban, illetve „népjobbító” tanaiban. ${ }^{124}$ A kor nemigen kedvez ezeknek a 'tudós' tanításoknak, valójában az erôviszonyok számítanak. Ezért is az a „,nyers kritika”, amellyel a hatalmi elit erénytani 'értékeit' illeti. ${ }^{125}$ Velük ellenkezően eszménye az archaikus kisközösség, vagy ha ez nem lehetséges, a kivonulás. A ,visszavonult bölcsek” álláspontja a konfuciánus müveltség (wen 文) írásbeliségre (wen 文) alapozott ,ékes beszédének” (wenyan 文言) elutasítása. A Laozi konfucianizmussal szembeni végsőkig vitt kritikai funkcióját mind a kínai hagyomány, mind a modern interpretációk hangsúlyosnak tekintik, és ez olyan evidencia, hogy itt felesleges részletesen foglalkozni vele. ${ }^{126}$ A Laozi-i eszményi életforma a ,természetközeli” kis faluközösségben való lét teljesen szemben áll a konfuciuszi kormányzási, hivatalviselési normákkal és erénytannal. ${ }^{127}$

Itt érdemes megemlíteni Feng Youlannak a megszokottól eltérő, de a taoista elgondolás egészéhez talán jobban illeszkedő értelmezését a visszavonultságot, zártságot reprezentáló ,nem-cselekvés” (wuwei 無為) terminus kapcsán. A „,nem-cselekvést” nem egyfajta szószerinti értelemben vett ,tétlenség"-ként érti, hanem a mesterséges, túlságosan kiterjesztett cselekvések kerülésekor, a dao szerint való, annak megfeleltetett cselekvésként, ${ }^{128}$ amely megelégedett közösségeket teremt. Amire itt újólag külön érdemes felhívni a figyelmet, hogy a Laozi ezt az egyszerü létmódú kis közösségiséget összeköti a nyelvhasználat és egy 'quasi-írásbeliség' egyszerüségével. „Legyen úgy, hogy az emberek ismét csomókat kötözzenek, s azokat használják (írás gya-

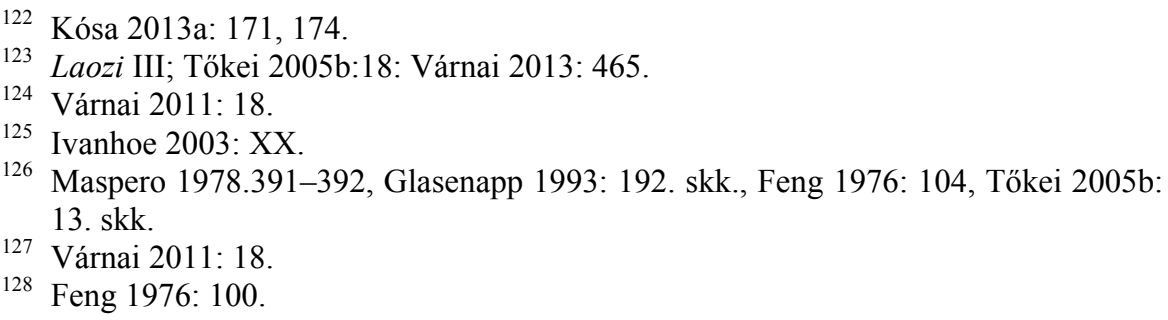


nánt).”; „A megbízható [xin 信] szavak [yan 言] nem szépek, a szép szavak nem megbízhatóak." 129 A Laozi ezen záró gondolata jelzi azt a paradoxont is, mely végigvonul a szöveg tanításának egészén, hogyan lehet „hitelt érdemlően beszélni” (xin yan), ha bölcshöz illöen, „szavak nélkül” (bu yan 不言) tanítunk.

\subsection{Zhuangzi -,a név (ming 名) ... a valóság (shi 實) vendége”}

A taoisták az „égalattin” (tianxia 天下) felülemelkedő, ott csak vendégeskedő életformát tulajdonítanak a bölcsnek, ${ }^{130}$ a Zhuangzi a bölcs (shengren 聖人) „misztikus” meg-érzést és az általa is daonak nevezett „teljességgel” való egyesülése útját helyezte előtérbe. ${ }^{131}$, „[...] a szent embernek (shengren 聖人) ... még neve sincsen (wuming 無名)", ${ }^{132}$ vagyis tökéletesen belehelyezkedett a daoba, a „határtalanságba (qiong [tkp. „végső” - V.A. ]) emelkedvén”" ${ }^{33}$.

Hogyan lehetséges, hogy képesek vagyunk a valóságról (shi 實) többékevésbé pontosan beszélni? Lehetséges-e erre törekedni? Vagy megoldásaink látszólagosak, hiszen a „vanság”, a „levés” (you) paradox voltáról szólnak. Az ilyen, és ezekhez hasonló kérdések kiélezése valójában a Zhuangzivel kezdődik. Zhuangzi az első, aki 'érdemben' foglalkozik ezzel a kérdéssel, vitatkozva a „nevek iskolája” (mingjia 名家) ,vitatkozóival” (bianshi 讋士). ${ }^{134}$ Érdemes kiemelni, hogy a Zhuangzi egyes fejezeteinek írója jól ismeri a motista kánonokat, illetve Hui Shi és Gongsun Long elképzeléseit, és tudatosan reagál ezek érvelésére. ${ }^{135}$

Zhuangzi veti fel, miként lehetséges az, hogy ugyanazon dolgokat egyesek így, mások pedig úgy írják le, miközben meg vannak arról győződve, hogy igaz „mondást” mondanak (yan), sőt, hogy ők adják a „valóság” (shi) egyetlen megfelelően pontos leírását? A bölcs ember (shengren) ez utóbbit semmiképpen sem gondolhatja Zhuangzi álláspontja szerint. A dolgok ugyanis ilyenek is és olyanok is lehetnek. ${ }^{136}$ A legkézenfekvőbb magyarázatnak tủnik arra,

${ }^{29}$ Laozi LXXX, LXXXI; Tőkei 205b. 45, Várnai 2011: 18.

30 Várnai 2013: 424.

131 Kósa 2013b: 190-191.

132 Zhuangzi I.1; Tökei 2005b: 59.

133 Zhuangzi II.10; Tőkei 2005b:73.

134 Várnai 2013: 415.

135 Kósa 2013b: 200.

136 Várnai 2011: 18. 
hogy valamit „olyan”-nak (ran 然) tartunk, az, hogy az adott dolog olyan. Ha pedig, ,nem-olyan”-nak (bu ran 不然) nevezzük ugyanazt a dolgot, akkor az nem olyan. A két dolog egymás mellett való megnevezése semmiféle feszültséget nem foglal magában, minden dologban megvan a lehetőség arra is, hogy másmilyen legyen. A bölcs felismeri azt, hogy a daoban nincs helyes (zheng 正) és helytelen (buzheng 不正), így aztán egyszerüen felesleges bármiféle harc a meggyőzésért.

A legfigyelemreméltóbb, a szöveg egészén átívelö paradoxon a Zhuangziben az a „módszertani” kísérlet, amelyben a mester a „pontos beszéd” követelményét állítja fel. A következőket fejtegeti: lehet a valóságról beszélni, mindössze arra kell ügyelnünk, hogy pontosan beszéljünk. „Aki azt, amit mond, szándékosan nem határozza [yan 言, ,mondja” - V.A.] meg pontosan, arról nem tudhatni, hogy végülis van mit mondania, vagy egyáltalában nincs mit mondania." ${ }^{137}$ Zhuangzi itt tulajdonképpen a „vitatkozókat” támadja, és azt mondja, hogy ,aki beszél, annak legyen mit mondania.”" ${ }^{138}$ Ámde ezek után így folytatja: ,,[...] Hogyan létezhetnek [you 有,,van”] olyan szavak [yan, ,beszéd"], amelyek lehetetlenséget (tartalmaznak)?"139 Vagyis amit a Zhuangzi szerzője állít, az éppen az, hogy azt észrevételezhetjük, ,úgy van” ( $s h i$ 是) és „nem úgy” ( $f e i$ 非) megkülönböztetései csak látszatok, a daoban minden egy, $\mathrm{s}$ a megkülönböztetés igénye, $\mathrm{s}$ a megkülönböztetések maguk látszólagos és valóságos paradoxonokhoz vezetnek. ${ }^{140}$

Zhuangzi úgy látja, hogy minden nézőpont érvényes, bár nem feltétlenül „van úgy” ( $s h i$ 是). Ugyanakkor ez nem jelenti azt, hogy semmilyen értelemben nincs kitüntetett perspektíva. Ugyan Zhuangzi „szkeptikus” a nyelvvel, s a „nevek” (ming 名) és a „beszéd” (yan) érvényességét illetően, ez nem jelenti azt, hogy tagadná magának a tudásnak a valóságát, de számára ez a tudás nem nyelvi jellegü. A Zhuangziben megjelenő kérdések a valóság és a tudás diszkrepanciáját tükröző nyelvi relativitás problémáját, a paradoxonok lehetségességének következményeit a gondolkodásra, $\mathrm{s}$ ennek folyományaként a tudás mikéntiségét vizsgálják, és mindezt a puszta érvelés hatékonyságával szembeni „,szkepticizmus" járja át. ${ }^{141}$

137 Zhuangzi II.3; Tökei 2005b: 65.

138 Zhuangzi II.3; Tökei 2005b: 65.

139 Zhuangzi II.3; Tőkei 2005b: 65.

140 Várnai 2013: 417.

141 Kósa 2013b: 191, 193. 
Azt mondjuk, amit valóban tapasztalunk, s ha ennek a feltételnek megfelelünk, akkor mindig úgy lesz, hogy ha egy dolgot „olyan”-nak neveztünk, akkor valóban olyan. Ez nem jelenti azonban azt, hogy akár ugyanabban a pillanatban, csak egy másik szemszögből ne lehetne „,nem-olyan” is. „Az ünnepelt szépségek az emberek között nagyon szépnek számítanak, de a halak víz alá merülnek, ha megpillantják őket [...] vajon melyik tudja hát, mi az égalatti leghelyesebb szépsége?"142 Nyilvánvalóan értelmetlen lenne azon vitázni, hogy kinek van „valódisága” ( $s h i$ 實), mindenkinek a mondandója „úgy van” (shi). Egyetlen, mindenki számára, mindig elfogadható „valódiság” (shi) nincs, ,úgy van”-ság és „,nem (úgy van)”-ság (shi fei 是非 ${ }^{143}$ ) eldönthetetlen [Tökei itt a shit ,,igazság”-nak illetve ,igaz”-nak, a feit „téved”-nek fordítja]. ${ }^{14}$

A Zhuangziben megnyilvánuló alapállás az, hogy a taoizmus tanítását szavakban továbbadni nem lehet, a beszéd nem vezérelhet. Világos megmutatkozása ennek az a példabeszéd (a XXI.3-ban), amelyben a 'taoista' Konfuciusz „beszéd nélküli” (buyan 不言), és tanítványai éppen ezért „hisznek” (xin 信) neki, „bíznak” (xin 信) benne, s így követik („You \{Confucius\} are believed even when you don’t speak [...]”). ${ }^{145} \mathrm{Az}$, hogy a taoizmus „módszere” (shu 術) ilyen, és a dolgok megértése csak közvetlen intuitív belátással lehetséges, paradox módon, a Zhuangziben a „dialógus” módszerének meglehetősen figyelemreméltó variációjával, a „kérdés-felelet” (wen-da 問答) eljárásával mutatkozik meg. ${ }^{146}$ A tudás átadásának ez a módja a dolgok 'negatív' megközelítését tartalmazza. Ennél a megközelítésnél hiányzik a dolgok analízise, elemekre bontása. Lehetnek a részletek önmagukban jók, de az egész mégis csak nem ,az”, az egész egységében való „hirtelen” megragadásával lehetséges csak az „az”-ságára rádöbbenni. Ez összefügg avval, hogy a tapasztalható jelenségek kölcsönösen elöidézik, eredeztetik egymást, és a tapasztalati világban nem fedezhető fel a mögöttük rejtező „végső” (qiong 穹), a dao. Emiatt a tapasztalható jelenségek, „képmások” (xiang 象) nem teljesen valóságosak, a dolgok „levése”, „vanságuk” (wuyou 物有) feltételekhez kötött, viszonylagos és múlandó. ${ }^{147}$

${ }^{142}$ Zhuangzi II.8; Tőkei 2005b: 71.

143 Karlgren 1996: 229 (866a, s), Schluessler 1987: 545, 546, Schluessler 2007: 464. Karlgren 1996: 155 (579 a-b), Schluessler 1987: 158, 159, Schluessler 2007: 232.

144 Zhuangzi II.10; Tőkei 2005b: 73.

145 Kósa 2015: 76.

146 Várnai 2011: 18.

147 Gabelentz 1953: 27-29, Chan 1973: 177-178, Hansen 1992: 137-138. 
A kérdés-felelet eljárásán keresztül a nyelvhasználat problematikája fontos részévé válik Zhuangzi tanításának. A nevek (ming 名) viszonyát a „levőkhöz" ( $w u$ 物) egyfajta konvencionalitásként kezeli, úgy gondolja, hasonlóan Laozihez, hogy a név pusztán utalás, ,a valóság ( $s h$ 實) vendége”. ${ }^{148}$ Ezzel az állásponttal azt rögzíti, hogy nem a szavak 'jelentéstartományáról' kell beszélni, hanem a dolgokról magukról. A vele egyidőben tevékenykedő vitatkozókról (bianshijia 讋士家) - köztük beszélgetőtársáról és bölcseleti vitapartneréről, „fogalmi ellenfeléröl”, Hui Shi-ről - adott kritikája ezen az elkülönböztetésen alapul. ${ }^{149}$ Hui Shi ennek az élénk vitakorszaknak az egyik legérdekesebb szereplője lehetett, akivel Zhuangzi hol évődő, hol éles vitákat folytat, s sajnos csak éppen a Zhuangziből szerzünk róla kortársi ismeretet, s akinek paradoxonai - melyek az európai vizsgálódókat Zénón apóriáira emlékeztették $^{150}$ - is csak a Zhuangziben maradtak fenn.

Észreveszi, hogy a vitatkozók paradoxonai a nyelv elemeinek révén történő 'jelentés-átszervezésekre' alapozódnak, ezt ő a nyelv tökéletlenségének tekinti, annak, hogy tudunk képtelenséget állítani, oly módon, ahogyan azt nem lehetne, ha a név megfelelhetne a dolgoknak. ${ }^{151}$ Magát a módot vitatja, amely szerinte nem megy túl a nehézségek felmutatásán, miközben hangsúlyos állítása azt mondja, hogy a beszéd nem ,(puszta [zu 足 „elég”]) levegőfúvás”. ${ }^{2}$ Arról, aki csak paradoxonokat mutogat, mondogat, nem tudhatjuk, áll-e mögötte valódi tudás. Ez azonban önmagában véve paradoxon, hiszen míg első jelentésére nézve a pontosság iránti igényét jelenti be, ugyanakkor ennek a „,mondás”-nak (yan) a 'magja': ,[b]eszélni nem levegö-fúvás”, arra int, hogy bizony az is, nem csak hangok kiadása.

További paradoxon, miként tudjuk, hogy a taoista alapgondolat lényeges eleme az, miszerint a dao müködése, deje 德 éppen ez a „levegőfúvás”: „Az Ég és Föld közötti tér épp olyan, mint a kovácsfújtató! Üres, és mégsem omlik össze, ha pedig mozog, egyre több jön ki belőle." ${ }^{\text {"153 }}$ Ez lehet a qi 氣 (,lehelet, levegő, pára”), avagy a taiyi 太-(„Nagy Egy”), ami „dao szülte”. ${ }^{154}$ Erről komoly fordítási és értelmezési vitákat folytattak. ${ }^{155}$ A nyelvvel kapcso-

148 Zhuangzi I.2; Tökei 2005b: 59.

149 Várnai 2013: 415.

150 Várnai 2011: 21.

151 Várnai 2011: 18-19.

152 Zhuangzi II.3; Tőkei 2005b: 65, Liu 1994: 49-52, Feng 1976: 113, Wu 1995: 54.

153 Laozi V; Tőkei 2005b: 18.

154 Laozi XLII; Tőkei 2005b: 32.

155 Ян 1950: 127-128, Maspero 1978: 395-396. 
latos problémák megoldása Zhuangzi számára nem fér össze azzal, hogy a vitatkozók módjára a nevek (ming 名) 'mikéntiségét' boncolgassa. A taoista álláspont szerint a merev fogalmak ugyanis sohasem alkalmasak arra, hogy céljukat betöltsék, hogy leírják azt, ami „egyszerre ez és az”. A dolgok változnak maguktól, és a vizsgálódó szemléletmódjától, ráadásul egyszerre és egyszersmind. Egyetlen ,állandó” tulajdonságuknak pedig éppen a változást kell tekintenünk, így nem tévedhetünk velük kapcsolatban. ${ }^{156}$

Zhuangzi megkísérli a véleménye szerinti hiábavaló 'bizonyosságokat' megrendíteni, éppen azáltal, hogy az előbbiek alapján mindig a viszonylagosságra mutat rá. Magát a „levő" ( $w u$ 物) sem tartotta egyértelmüen megragadhatónak, a maga konkrétságában, 'éppen adott voltában', „van”-ságában (wuyou 物有). Leghíresebb példázata is ezt a paradoxont mutatja fel:

„Egyszer régen Zhuang Zhou 莊周 azt álmodta, hogy ő pillangó, csapongó pillangó, amely szabadnak és boldognak érzi magát, és mit sem tud Zhouról. Hirtelen azonban felébredt, és íme, ő volt az, a valóságos Zhou. Most aztán nem tudom, vajon Zhou álmodta-e hogy pillangó, vagy talán a pillangó álmodja éppen, hogy ő Zhou? Pedig Zhou és a pillangó között biztosan van némi különbség. Íme ezt nevezem a dolgok ( wu 物) átalakulásának (hua 化)."157

Igencsak érdemleges feladatnak kínálkozna összevetni ezt a megoldást Platón Szókratészének álom-argumentációjával: „Ugyan miféle bizonyíték birtokában mondhatná ki valaki, ha éppen most, ebben a pillanatban azt kérdeznék tőle: vajon alszunk-e és mindazt, amiről gondolkodunk, álmodjuk-e csupán, vagy ébren vagyunk, és ébren beszélgetünk egymással?"158, de ez túlfeszítené a jelen kérdés tárgyalásának kereteit.

A pillangó 'hasonlat', akárcsak a „Dolgok egyenlősége” (Qiwulun 齊物論) fejezet egésze, Zhuangzi látásmódjának kettősségét mutatja. Egyszerre van helye a dolgok relacionalizálásának és ,egyenlőségének” ( $q i$ 齊, „,egyezőség”, „egységesség”, „megfelelőség”, „kiegyenlítődés”, „rendezettség”, „párosság”, „sorban”, „ugyanúgy”, „egyező helyzet”159).

156 Liu 1994: 49-52, Gabelentz 1953: 27-29.

157 Zhuangzi II.12; Tőkei 2005b: 74.

158 Platón: Theaitétosz 158b-d; PÖM II. 935-936.

159 Karlgren 1996: 158-159 (593a-e), Wieger 1965: 576, Schuessler 1987: 468, Schuessler 2007: 421. 
A Zhuangzi e fejezetében ugyanakkor tere van egy lehetséges ,misztikus” kilépésnek is ebből a viszonylatból: ,a legjobb, ha igazi világosságra (ming 明) törekszünk”. ${ }^{160}$ Ugyanúgy jelen van a „szkepticizmus”, egyfajta racionális elemzésben illetve a ,miszticizmus” egy aracionális 'eltávolodásban', utóbbi a „határtalanságba [qion $g$ 窮, ,,végső”] távozás” révén az ,igaz ember”-ben (zhenren 真人 - a zhen 真 jelentései ,valódi”, „,valóságos”, „megvalósuló”, ,igazi”, „kipróbált"161) 'ölt testet'. Az ,,igaz ember” az eszményi taoista, aki teljes mértékben a daoval összhangban él, a külvilágtól elszakad abban az értelemben, hogy nem rabja annak többé, és „szabadon kóborol” (xiaoyao 逍遙), hiszen nincs, ami gúzsba kötné. ${ }^{162}$

Zhuangzi minden konvencionális megkülönböztetést és dualitást igyekszik felszámolni, hiszen úgy véli, hogy végső soron a dao felől nézve a megkülönböztetések értelmetlenek. Nem úgy véli, hogy a valóság álomszerü, hanem hogy nincs módunk inkább valóságosnak tekinteni az ébrenlétkor tapasztalt világot, mint az álomét. Egy adott állapot kitüntetettként kezelése azért sem lehetséges, mivel az állandó váltakozás, az egymásba történő folytonos átalakulás adja a valóság alapvető vonását. ${ }^{163}$ „Az ébrenlét és az álom szétválasztása nem különbözik a halál és az élet közötti különbségtevéstől”- mondja a kommentátor Guo Xiang. Valójában Zhuangzi „A dolgok egyenlőségéről” fejezetben épp azt mondja, nincs különbség, ,innen nézvést ez, onnan nézvést az". Zhuang Zhou kételkedik és reflektál saját álombéli és ébrenléti állapotára. Ha álmunk közben nem vagyunk tudatában, hogy álmodunk, akkor az ébrenlétben sem tudhatjuk, hogy az nem 'álomszerü'-e. ${ }^{164}$ A szöveg egyértelmüen az álombeli és az ébrenléti állapot „,relativitásáról” beszél, miközben ugyanakkor a két állapot közti különbséget is rögzíti, így beszélve a 'levők' (wu) átalakulásáról. A pillangó a bábból kiszabadultan ,szabadon” csapongó - a fizikai, társadalmi, nyelvi konvencióktól szabadult ,igaz ember” (zhenren 真人) szimbóluma, ${ }^{165}$ hiszen az átalakulás (hua 化) ,a maga olyanságának” (ziran) keretei között történik.

Zhuangzi itt bizonyos értelemben eldönthetetlennek tekinti, hogy a tárgyi világunkról való tudás a tapasztalati megragadás 'mindenhatóságára' alapoz-

160 Zhuangzi II.3; Tőkei 2005b: 66.

161 Karlgren 1996: 106-107 (375a), Schuessler 1987: 822, Schuessler 2007: 610.

162 Kósa 2013b: 196.

163 Kósa 2013b: 201.

164 Kósa 2008: 97-98, 100.

165 Kósa 2008: 104-105, 106. 
ható-e. Az, hogy közös képet (xiang 象) formálunk a valóság (shi) felöl, hiába kezeljük biztosítékként, nem bizonyítja a 'jelenségek' (xiang 象) jelenvalóságát (shi), csak jelenésszerüségét (xiang 象). Zhuangzi a születés és halál közé eső időt egy folyamat - vissza-visszatérő (hol yin, hol yang) - szakaszának tekinti. Az emberi élet kitüntetettségét kikezdi, sőt, egy lépéssel tovább „hatol”, amikor egy fehér ló vágtatásának egyetlen szakadék feletti ugrásához hasonlítja földi „,pályafutásunkat”. ${ }^{166}$

Aki képes annak felismerésére, hogy a dolgok lehetnek ilyenek és olyanok, vagyis sokfélék, de sokféleségük voltaképpen „egyik oldalról” tekintve „ez” és „más oldalról” tekintve „az”, s mégis valamilyen egységességben 'rejlenek', az „bölcs embernek nevezhetö”. Egy ember álláspontja tehát elrendezés, választás és megkülönböztetés révén jön létre, $s$ ha valaki csupán egy szemszögből szemléli a dolgokat, akkor csak egy részigazságra tehet szert. A bölcs ember tudja, hogy hogyan van az „ez” ( $s h i$ 是),de azt is tudja, hogy hogyan van az ,az” ( $b i$ 彼), és érti azt is, hogy az „ez” voltaképpen nem különbözik az „az”-tól. Mindegyik ugyanannak a 'levésnek' részeit jelenti. „Ezért a bölcs ember (shengren 聖人) nem ezekből indul ki, hanem az ég fényében látja a dolgokat”, és ,világosságra (ming 明) törekszik”. ${ }^{167}$ Így hát a Zhuangzi a megkülönböztetés (bian 辨) értelmezhetetlenségéröl, s értelmetlenségéről beszél.

Zhuangzi annak a belátását tekinti valódi, „világos” megismerésnek, hogy a dolgok ,kezdettől fogva összhangban vannak a határtalannal” [qiong], a daoval. A világos megismerés ugyanis azt jelenti, hogy a dolgok mutatkozhatnak ilyennek is és olyannak is, de nem megfelelö felfognunk az „ez”-t (shi 是) meg az „az”-t ( $b i$ 彼) különállóként, párként, csak a daoval való „egységükben”. A dao, mint ,fordulópont körül, mint közép körül”, annak 'hatására' (de) müködnek az ,ez-az”-ok, ,az-ez”-ek. ${ }^{168}$

A Zhuangzi-nek a megnevezés (ming 名) kapcsán megfogalmazódó állításai egy „szkeptikusként” is jellemezhető felfogásmódot tükröznek.

„Ha létezik [you, „van”] lét [you, „van”], akkor létezik [you, „,van”] nemlét $[w u$, ,nincs"] is, sőt, van, amikor a nemlét [wu, ,nincs”] létezése [you, ,van”] még nem kezdödött el [...] a létböl [you, ,van”] a nemlétbe $[w u,$, nincs"] (jutunk) és nem is tudjuk, hogy a nemlét [wu, „nincs”] létezése [you, „van”] voltaképpen létezés-e [you, „van”], vagy

166 Zhuangzi XXII; Maspero 1978: 398, Wilhelm 1940: 185-186, Chan 1973: 208-209.

167 Zhuangzi II.3; Tökei 2005b: 66.

168 Liu 1994: 57, Várnai 2011: 19. 
pedig nem-létezés [wu 無, ,nincs”]. Sőt már van is mivel beszélni a dologról, pedig azt sem tudjuk, hogy amit mondunk róla, annak [...] van-e $[y o u]$ valami mondanivalója, vagy pedig nincs $[w u][\ldots] . " 169$

A kérdésfeltevés tehát a valóság (shi) megragadhatóságára vonatkozik annyiban, amennyiben a folyamatjellegre, az átalakulásra, átváltásokra (hua 化) kérdez rá, miközben azt hangoztatja, nem is tudunk mit mondani erről. A kérdezés célja tehát nem a kérdés megválaszolása, hanem egy olyan határ kijelölése, amelyen túl a ,határtalan” [qiong] dao az ilyenfajta kérdést értelmetlenné teszi, és amely így tisztázhatatlanná válik. Tehát nem egy tartalmi kérdés, hanem bizonyos értelemben egy retorikai eszköz, mely magát a kérdezést, a kérdést önmagát függeszti fel. Az előbbi kérdésre Zhuangzi konklúziója ugyanis a következőképpen nyer megfogalmazást: „[...] akkor hogy is akarnánk a létből [you] kiindulva haladni a lét [you] felé? Ezzel sehová se jutnánk. $\mathrm{Az}$ »ez«-re [shi] való támaszkodásnak tehát véget kell vetni." "170 Ennél a fejtegetésnél is jó tudnunk, hogy a „lét”-,,nemlét” fogalompár a fordító -a sinológiai 'hagyományt' követő - interpretációja, amivel az a probléma, hogy azok az európai filozófia metafizikai funkciót is betöltő ontológiai kategóriái, és használatukkal félreértjük a kínai bölcselet mondandóját.

Miről is van szó? A mi görög filozófiai hagyományunkról. Parmenidész

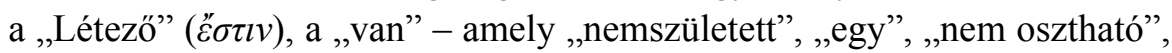
„,változatlan” és "tökéletes”- és a 'dolgok' sokasága - amely „látszat” - megkülönböztetésével és jegyek tulajdonításával operál. A legfontosabb megkülönböztetések a dolgok, 'a létezők' ( $\tau \alpha$ őv $\tau \alpha)$, az összes dolog, 'mindenek' ( $\tau \alpha$ $\pi \alpha v \tau \tilde{\alpha})$ illetve a minden egyes, 'mindegyik' fogalmaiban találhatók meg. Empedoklész ezt gondolja a világ müködéséről: „Egyszer a Szeretet révén mindenek eggyé egyesülnek, majd meg ismét egyesekké válnak szét a Viszály ellenségeskedése révén.” (Empedoklész B17, 7-8); Hérakleitosz pedig ezt: ,Mert [...] minden e Logosz szerint történik [...] a dolgok [...] mindegyikét fölbontom annak valódi természete szerint, és megmutatom, hogyan van." (Hérakleitosz B1) A ,filozófiai tudományok szisztematikus tudományok" a Platón tanítvány Xenokratész óta; elgondolható, érzékelhető, illetve érzékeléssel és gondolkodással megismerhető szubsztanciákra vonatkozó tudományok. Arisztotelész ,egy létező szubsztanciáját” annak mibenléte, funkciója alapján tartja meghatározhatónak, szükségszerüen igaz kijelentések által,

169 Zhuangzi II.6; Tökei 2005b: 69.

170 Zhuangzi II.6; Tőkei 2005b: 69, Maspero 1978: 392, Allinson 1990: 47-49. 
amelyek megalapozzák a tudományt. A kijelentések igazságértéke kapcsán azt tételezi, hogy a kijelentés szerkezete izomorf a valóságnak avval a darabjával, amelyről szól. Megkülönböztet önálló létezőket (szubsztanciákat) és önállótlan létezőket (attribútumokat), és e létezö-osztályokon belül általános és egyedi létezőket. A szubsztancia és attribútumainak kilenc osztálya együtt alkotják a kategóriarendszert. Ez a fajta elemzés két szempont alapján történik, elsősorban metafizikai szempontból, ez a kategóriatan; másodsorban logikai szempontból, amely az individuumok, speciesek és genusok alá-fölérendeltségét osztályozza. A felosztásban rendkívül fontos mozzanat, hogy nyelvünk és gondolkodásunk szerkezetében mindkét szempont látensen jelen van. Ez a kategoriális létszerkezet oly evidens számunkra, hogy elgondolni, sőt elképzelni sem tudjuk, hogy lehetséges a világot másképp felfogni, szemlélni. ${ }^{171}$ Cristoph Harbsmeier kiemeli, hogy ettől eltérően a kínai bölcseletben a gondolkodásmód létrehoz terminológiai sémákat, amelyek értelmezése nagyon alapos szövegelemzéseken alapuló vizsgálatokat kíván ahhoz, hogy ezeket valóban megfelelően hasonlíthassuk össze a görög filozófiai nyelvhasználattal, vagy a modern európai filozófiai nyelvhasználattal. ${ }^{172}$

Most térjünk vissza a taoista tanításhoz. Az égalatti múködésébe, a tízezer dolog (wanwu 萬物) egymást váltásába való bármiféle beavatkozástól ódzkodó tartózkodást jól példázzák a következő megjegyzések. „Aki tehát örül annak, hogy hatással van a dolgokra ( $w u$ 物), nem igazán bölcs ember."; „mert a dao [az], amelynek van lényege (qing 情 [,,helyzet”, „sajátosság”]) és van megbízhatósága (xin 信), de nincs tevékenysége (wuwei 無為) és nincs testi formája [wuxing 無形]. ${ }^{, 173}$ A qing terminus „lényeg”-nek fordítása elég pontatlan, túlértelmező.

Zhuangzi osztozik a Laozivel abban, hogy nevekkel nem lehet leírni a Daot, az „Utat”. Fundamentális szkepszise általában a nyelvet illeti. Eléggé paradox, hogy - az ókori kínai bölcselők között - „kétség nélkül ő az egyik legnagyobb író, aki a szavakkal bánik". ${ }^{174}$ Mindent a megnevezhetetlen daora vezet vissza, s ez nyilvánvaló. A megnevezésen (ming) keresztül a valóságot nem tartja megragadhatónak, csak bizonyos megszorításokkal értelmezhetönek. Evvel szemben a konfuciánusok valamint a legisták az „egyenes”, helyes megnevezést (zheng ming 正名) megfelelő segítségnek tartják a valóság

171 Várnai 2013: 425-426.

172 Harbsmeier 1998:217-218.

173 Zhuangzi VI.1; Tőkei 2005b: 78, 80.

174 Ivanhoe 1993: 639. 
(shi) rendbetételéhez. A vitatkozók iskolái pedig megkísérlik, hogy a nyelvhasználat felől értelmezve a valóságot, elfogadják azt. Alapvető különbség a taoisták és a nyelvvel operáló vitatkozók iskolája között az a súlyponteltolódás, amely egyik oldalon ahhoz vezet, hogy a daot helyezve mindenek fölé, a nyelven keresztüli értelmezést elvessék, míg a másik oldalon a praxis és megnevezései felől megelégszik a „való” ( $s h i$ 實) a neveken (ming 名) keresztüli 'befolyásolásának' kísérletével, valami olyasféle reflexióval, hogy a helyes megnevezés és nyelvhasználat valóságra gyakorolt hatása egyben a daonak a megvalósulása az égalattiban. ${ }^{175}$ Mindezt persze Hui Shi eleve, Gongsun Long pedig eredményét tekintve sikertelennek ítéli, mert név és való viszonya paradoxiális. ${ }^{176}$

„Hogyan létezhetnek [you 有, ,van”] olyan szavak [yan 言 „beszéd”], amelyek lehetetlenek?" ${ }^{177}$ Itt először is valami fontosat érdemes megjegyezni. A szövegből látszik, hogy a megfelelő kifejezések felhasználásával a szerző, miközben paradoxonalkotást vet a vitatkozók szemére, maga is nyelvi paradoxonokat alkot. A fenti ilyen paradoxon. A szerző azonban ezen is túllép, és valóságparadoxont is megfogalmaz. Mégpedig olyat, amely Zhuangzi és Laozi dao-felfogása közötti valóságparadoxont is megjeleníti némileg. Míg a Laoziben a dao „maga homályos”, (yin, „rejtett”, „rejtőzködő”) és szerzője azt írja: „én vagyok maga a homály”, ${ }^{178}$ addig a Zhuangzi az „elhomályosodhatóságról”, „elfedődöttségről” (yin) mint problematikusságról, nehézségről, gondról beszél.

Ugyanígy egyszerre nyelvi és valóságparadoxonok az „ez” ( $s h i$ 是) és az „az” ( $b i$ 彼) relációi is, amelyek „egy-egy oldalról jellemzik az életet.” ${ }^{179} \mathrm{Itt}$ érdemes valamit kiemelni: A kínaiban nem alkalmaztak idézőjeleket megkülönböztetéseikben, amikor a terminus referál valamire a világban, és amikor utal arra, amire vonatkozik, ${ }^{180} \mathrm{~s}$ így a fordítás-interpretációkban szétválasztják ugyan a valóságra referálást és az utalást, de ez az eredetiben nem így áll.

A ,levőket”, dolgokat ( $w u$ 物) ,ez”-re és ,az”-ra bonthatjuk, az egységet különbözőségekre választjuk szét. „A [...] daonak 道 nincs kezdettől létező körülhatároltsága (youfeng 有封); a szavaknak nincs kezdettől fogva létező

175 Gabelentz 1953: 33-34, Liu 1994: 63:

176 Várnai 2013: 470.

177 Zhuangzi II.3; Tökei 2005b: 65.

178 Laozi XX, XXI; Tőkei 2005b: 23.

179 Zhuangzi II.3; Tökei 2005b: 65.

${ }^{180}$ Hansen 1981: 327. 
állandóságuk. Csak az »ez« szempontjából jönnek létre a megkülönböztetések. [...] Mert amit szétválasztanak, az szétválaszthatatlan". ${ }^{181}$ Itt némi kommentár szükségeltetik. A you (,van”) itt a „meglevő körülhatároltságok” daot nem érintő voltáról mond valamit, s értelmetlen „létező”-nek fordítani. Az „ez” (shi) azonban nem csak a dolgokat, azok egyik oldalát, „körülhatároltságát” (feng 封, „határ”, ,határvonal”, ,gát”, „töltés”182) jelentő kategória, hanem egyben a szemlélö, megfigyelő helyének aposztrofálásaként is felfogható. Tehát az „ez” ( $s h i$ 是) ebben az értelemben magát a megkülönböztetéseket tevőt, a dolgokat felosztót, magát a kijelölö embert is jelölhetné.

Különösen akkor válhat egy ilyen értelmezés vonzóvá, ha az „ez” (shi) és az „én” (wo) adott szövegben való 'együttlétét' tekintjük: „Ha az »ez«-t megvalósításnak (cheng 成 [,teljesít”, „felhalmoz”, „töltés”183]) lehetne nevezni, akkor énünk (wo) is megvalósítás lenne. Ha azonban az »ez«-t nem lehet megvalósításnak nevezni, akkor sem a dolgok ( $w u$ 物), sem az én ( $w o$ ) nem jelentenek megvalósulást." ${ }^{\text {"184 }}$ Itt nagyon könnyen hajlamosak lehetünk az európai kategóriák használata felől értelmezni. Ennek a vonzódásnak ellenére ezek a gondolatok nem az ember, az „Én” megismerésben játszott, „lét-megértő” kitüntetett szerepét hivatott felmutatni. Valójában arra próbál rávilágítani, hogy az „ez”-ből (shi) kiinduló megkülönböztetésekre alapuló megismerés nem érheti el sem a „dolgok olyanságát” (wu ran), sem a megkülönböztethetetlent, az „egyet” ( $y i$-), és mögötte magát az eredetet. Vagyis nem juthat el a daohoz a maga olyanságában (ziran). ${ }^{185}$

A vitatkozó Gongsun Longzi írásaiból kivehetően maga is tisztázandónak, rendbeteendőnek tekinti a megkülönböztetések (bian 辨) nehézségét, $\mathrm{s}$ bár egyértelmü, körülhatárolt választ nem ad, egyfajta irányt kijelöl.

„Ezért az a kívánatos, hogy az »az« korlátozódjék »arra«, az »ez« pedig korlátozódjék »erre«; és megengedhetetlen, hogy az »az« lehessen »az« is, meg »ez« is, az »ez« pedig lehessen »ez« is, meg »az« is. Mármost a név (ming): egy valóság megnevezése. Ha pedig tudjuk, hogy ez nem ez, és tudjuk, hogy nincs jelen az ez, akkor nem is szabad így nevezni. Ha tudjuk, hogy az nem az, és tudjuk, hogy az ott

181 Zhuangzi II.7; Tőkei 2005b: 69-70.

182 Karlgren 1996: 308-309 (1197i), Schuessler 1987: 165, Schuessler 2007: 237.

183 Karlgren 1996: 216-217 (818a-d), Schuessler 1987: 71, Schuessler 2007: 185.

184 Zhuangzi II.5; Tőkei 2005b: 68.

185 Allinson 1990: 84-85. 
nincs jelen, akkor nem is szabad így neveznünk. Ó, mily tökéletesek voltak a régi idők bölcs királyai! Mindig megvizsgálták a nevek és a valóság (megfelelését), s nagyon vigyáztak arra, hogyan nevezzék meg [...]." ${ }^{, 186}$

„Mármost a név (ming): egy valóság megnevezése” - mondja Gongsun Long „A névről és valóságról” fejezetben, vegyük észre, hogy ez radikálisan szembenáll Zhuang Zhu 'tézisével': ,a név [名] a valóság (實) vendége”. ${ }^{187}$ Gongsun Longzi szerint vigyáznunk kell tehát arra, hogy amikor egy dologról beszélünk, akkor úgy válogassuk meg szavainkat, hogy arról és csak arról beszéljünk, amire valójában gondolunk, ezáltal a pontosságigényt értékeli újra, de mivel az nem kielégíthető, ezért vezet paradoxonokhoz az ö megoldása is.

Zhuangzi megismerés-kritikája egy olyan állapot elérését kísérli meg célul kitüzni, amely a dao és az ember közötti eredeti viszonyhoz való visszatérés, melyben a megismerés még nem bontotta meg az egységet, mint később, a szavak kijelölö, szétválasztó funkciója folytán. Ha nem történik meg az „ez”-nek - mind a megkülönböztetettnek, mind a megismerőnek - az ,elhagyása”, az ,arról” és a ,róla” való lemondás, akkor a „levők” (wu 物) szétválasztása miatt a shi 是 („úgy van”) és fei 非 („,nemúgy”) „különbségének megmutatkozása által a [...] dao csorbát szenvedett."188

A Zhuangzi bölcselete az „ez”-röl való lemondást az „én” meg-nem-valósításaként értelmezhette, és általa vélte lehetőségnek biztosíthatni a ,visszatérést" a dao-hoz. A dao megértése nyelvi úton a megismerő én megkülönböztetéseket alkalmazó módszere révén nem lehetséges. Figyelembe véve bizonyos taoista meditációs technikákat, amelyek a Zhuangzi meglehetősen misztikus tartalmú egyes szövegrészeiben is fel-felbukkannak, úgy tünik, ezek révén vélhettek elérni a daohoz. Igen nehéz kérdés, hogy értelmezhetjük-e egyáltalában, mennyiben köthető ezek után az elérés valamiféle „én”-hez, s ki vagy mi válik eggyé a daoval? A Zhuangzi szövege alapján a dao megértését talán úgy lehet felfogni, mint a dao megjelenését az arra felkészült emberben, s az ember „világosságra (ming 明)” törekvésében is valamiféle őseredeti

186 Gongsun Longzi VI; Tőkei 2005b: 146.

187 Zhuangzi I. 2; Tökei 2005b: 59.

188 Zhuangzi II.5; Tőkei 2005b: 68, Chan 1973: 193-194. 
„egybeesésre”, olyan viszonyra utalhat, amely a nyelv valóságot megosztó funkcionális használata következtében megszakadt. ${ }^{189}$

A dolgok eredendő állapota „olyanságuk” ( $r a n)$, amely nem az ember megnevezése (ming) kapcsán válik olyanná, azzá, hanem az ember „kijelölése”, megkülönböztetése előtt már őrzi „magaságát” ( $z i$ 自). A „levők”, a dolgok $(w u)$ nem lesznek azzal megismerhetőek, ha őket névadás és vitatkozás útján megkülönböztetjük, hiszen ez az eljárás, és müvelet „olyanságukat” nem érinti. Van, „aki [...] erőltetve igyekszik megvilágítani az eggyé-válást, de nem képes megérteni a dolgok azonosságát (tong 同)" ${ }^{190}$ A Zhuangzi bölcseletének végpontja tehát „,a dolgok azonosságának”, egységének, „összhangjának” (tong ${ }$ 同 ${ }^{191}$ ), egységként ,levőségének” (wuyou 物有) felmutatása, amely az „ez”-re való támaszkodás felszámolása nélkül elképzelhetetlen, hiszen csak így képes a dao eléréséhez vezető „világosságot” (ming 明) elnyerni. Ez a világosság nem más, mint az az állapot, amelyben az ember nem szorul arra, hogy „a hatalmas daot" megnevezze.,, [A] legmagasabb fok, ha tudásunk megáll ott, ahol a megismerhetetlen kezdődik.” ${ }^{192}$ A tong terminus fordításánál az „azonosság”-ként való értelmezés eléggé problematikus. Az ideogramma „egységet” jelent, már az archaikus szövegekben a da tong 大同 (,nagy egység”, „nagy harmónia”) szerepel, mint az Ég és az égalatti összhangjának terminus technikusa, s így a Zhuangzi miszticizmus felé hajló taoista jelentésértelmezése valószínűsíthetően ugyanezért alkalmazza.

A Zhuangzi még az egymásba átalakuló párokként „ez”-ként (shi), ,az”ként (bi), yin-yangként való felfogást, sőt még a párok 'meglétét' is megkülönböztetettként, nem valóságosként, az egység helytelen szemléléseként kezeli. ${ }^{193}, \mathrm{Az}$ »az«-t [ $b i$ 彼] és »ez«-t [shi 是] sohasem fogni fel [...] párnak: ezt nevezzük a [...] dao fordulópontjának." ${ }^{194}$ Így maradhatnak a dolgok összhangban a daoval.

„Az út (dao 道) azáltal tökéletesedik, hogy járnak rajta; a dolgok azáltal lesznek olyanok (ran 然), hogy (olyannak) mondják öket. [...] Azért tartják olyannak őket, mert olyanok. [...] Nincs dolog, amely ne lenne

\footnotetext{
189 Maspero 1978: 393-395, Maspero1933: 253.

190 Zhuangzi II.4; Tökei 2005b: 67.

191 Karlgren 1996 (1176 a-c) 303.

192 Zhuangzi II.7; Tökei 2005b: 70.

193 Várnai 2013: 438.

194 Zhuangzi II.3; Tökei 2005b: 66.
} 
(ilyen vagy) olyan; s nincs dolog, amelynek ne lenne lehetősége [(neng 能) „képessége” - V.A.] [...] mindaz ami »ez« [...] a dao révén egygyé lesz." 195

Hogyan alakult ki és müködik a minden dolgok különbözősége, a „külvilág”? Hogyan szüntethető meg ez a különbözőség és hogyan térhetünk vissza a dao egységébe? A régiek tudására hivatkozva Zhuangzi kijelöl a tudás számára egy végső pontot. Itt nem csupán az egyes tudásszinteknek való megfeleltetésről van szó, hanem az égalatti valóságszintjeinek való megfeleltetéséről is. $\mathrm{Az}$ eredeti, s egyszersmind végső (qiong) egy olyan állapot, amikor a dolgok létezése még nem kezdődött el. A következő szint, amikor már léteznek a dolgok, de körülhatároltságuk még nem történt meg. Ez a tulajdonképpeni „egy-állapot”. Ezután a dolgok körülhatárolódnak (youfeng 有封), de még nincs elkülönböződésük, megkülönböztetésük, még nincsenek megnevezve, meghatározva helyesnek vagy helytelennek. Utolsó lépésként ez is megtörténik, ezáltal a dao mintegy „,csorbát szenved”. Ami pedig a daot „fogyatékossá teszi”, az az egyesben kialakítja a külvilág iránti vágyat. ${ }^{196}$

A megoldás arra, hogy eggyé legyünk a daoval, bizonyos értelemben a bölcs visszafelé haladása ezen az úton, hogy a „van”-ból (you) elérjen a „nincs”-hez $(w u)$. Ebben az összefüggésben megfogalmazódik a kérdés amely a pillangó hasonlatban is megjelenik -, milyen értelemben van egyáltalán a „,valóság” (shi), van-e, és mit jelent „kifejlődés” és „megfogyatkozás”. „Ha [van], Zhao mesternek pengetnie kell lantját. Ha nem, [...] pengetnie sem kell a lantját." Zhao pengette a lantját, [...] Huizi <előadta tanait> [...] [Mindegyik a sajátját] akarta megvilágítani, és »a kemény és a fehér« [...] homályában rekedtek meg. [...] <tanítványaik> pedig múvészetük (wen 文) fonalaiba bonyolódtak"- mondja a Zhuangzi. ${ }^{197}$

Zhuangzinek a vitatkozókkal való polémiája arról folyik, hogy vajon a nyelv miképpen követi illetve mutatja fel a „való”-t, és hogy e követés vagy felmutatás megoldást nyújt-e egyáltalán valamire. A Zhuangzinek ez a parafrázisa teljes ironikus vértezetében tárja elénk a vitatkozók szövegkezelésének általa vélt értelmetlenségét: Ha van kezdet, akkor kell lennie egy kezdet elötti állapotnak is, amikor a kezdet még nem kezdett el lenni. Hogy tovább szőjük és bonyolítsuk, kell lennie egy olyan állapotnak is, amikor még a „len-

195 Zhuangzi II.4; Tőkei 2005b:66-67.

196 Zhuangzi II.5; Tőkei 2005b: 68, Maspero 1971: 143-144.

197 Zhuangzi II.5; Tökei 2005b: 68. 
ni-nem-kezdett-kezdet" sem kezdett el lenni, és így tovább. Ugyanilyen gondolatmenettel lehet kezelni a „levés”-t, a „van”-t (you): ha van „levés”, van „nem-levés”, a „nincs” (wu) is. Kell lennie olyan állapotnak, amikor a „nemlevés” levése sem kezdődött el, sőt, amikor még ez a „lenni-nem-kezdődöttnem-levés" sem volt. ${ }^{198}$ Zhuangzi szerint ezekbe a gondolatmenetekbe azért felesleges belebocsátkozni, mert egyfelöl még azt sem lehet tudni, hogy a „nem-levés levése” tulajdonképpeni „levés-e” vagy pedig „nem-levés”, másfelöl, azt sem tudjuk, hogy amit mondunk róla, annak van-e egyáltalán valami mondandója, vagy sem. Így értelmezi a vitatkozók paradoxonait is, mint például a két híres Hui Shi apóriát: „A hatalmas hegy kicsiny.”; „Senki sem érhet el magasabb kort, mint a holtan született csecsemő." Ha az ég és a föld, és minden dolog a valóságban egyet alkot, akkor a levésre és a nem-levésre találhatunk-e egyáltalán neveket. „Az egy és a szavak kettő; a kettő és az egy három.” És így tovább...- bármeddig haladhatunk. Ha a „nem-levésből” indultunk ki, és így értük el a „levést”, s végül még a „háromhoz is eljutottunk”, akkor a „levésből” kiindulva haladni értelmetlen, nem vezet sehová. ${ }^{199}$ Csakhogy belső, sajátmaga - és a Laozi - tanítására is vonatkoztatható ez az „értelmetlenség”, hiszen maguk is „szövegkezelést” végeznek, s ezzel paradoxont 'hordoznak', ahogy arról már a Laozi kapcsán szó volt.

A Zhuangziből világossá válik, hogy szerzője szerint annak megállapításánál, hogy a valóságot meg tudjuk-e ragadni, nagyon nagy nehézségekbe ütközünk, a kérdés, hogy ki látja jól a „valóságot” eldönthetetlen, és így értelmetlen is. ${ }^{200}$ Zhuangzi úgy látja, a megkülönböztetéseknek, vitáknak, érveléseknek csak a hiábavalósága nyilvánvaló. „S ha ez így van [...] az emberek egyaránt képtelenek egymást megérteni, és valami egészen másra szorulunk [...] emelkedjünk a határtalanságba, s legyen otthonunk a határtalanság! [qiong] ]. ${ }^{201}$

A daohoz való eljutás megköveteli az „égalatti”-ból (tianxia) az emberek hierarchikus világából, a civilizációból való kilépést. Alapvető különbség a Laozihez képest, hogy a Zhuangzi szerint a valódi bölcs teljesen visszavonul a kormányzás evilági feladataitól. ${ }^{202}$ Zhuangzi éppen ezért visszautasította a kormányzásban való részvételt, amikor hivatalt kínáltak neki: „két főhivatalnok (dafu 大夫) azt az üzenetet hozta, hogy a király szeretné rábízni országá-

198 Zhuangzi II.6; Tőkei 2005b: 69, Wieger 1922: 74.

199 Zhuangzi II; Tökei 2005b: 69, Hansen 1992: 89.

200 Várnai 2013: 459-460.

201 Zhuangzi II.10; Tőkei 2005b: 73, Allinson 1990: 126, Maspero 1978: 397, 399-400.

202 Kósa 2013b: 190. 
nak kormányzását. [...] Zhuangzi pedig azt mondotta: Menjetek utatokra." ${ }^{203}$ Amikor meglátogatta Huizit, és a történet szerint Hui Shit azzal csapták be, hogy hivatalát jött elfoglalni, Zhuangzi igen neheztelt rá, hogy hitt ennek. ${ }^{204}$ Egyáltalán nem volt hajlandó feladatot ellátni. Egy metaforán keresztül azt kívánta érzékeltetni, hogy „szolgák [...] nem méltók rá, hogy egymást kormányozzák [...] egész élet szüntelen szolgálat [...] érdemes eredmény [...] nélkül [...]”, azonban „,a bölcs ember (shengren 聖人) megbékít”" ${ }^{205}$

„Yao át akarta engedni az égalattit Xuyounak, és így szólt: Ha te állnál a trónon mester, az égalatti rendje biztosítva lenne, ha pedig továbbra is én foglalnám el ezt a helyet, fölöslegesnek látnám már magamat. Kérlek tehát, vedd át az égalattit. Xuyou azonban így felelt: Most te kormányzod az égalattit, s az égalattiban régen rend uralkodik. Ha én mégis elfoglalnám a helyedet, akkor én csak név (ming 名) lennék! A név azonban: a valóság ( $s h i$ 實) vendége. Lehetek-e hát csak név?"206

Itt, ebben a szövegrészben a ,valóság” (shi) mibenléte nem kerül tisztázásra. ${ }^{207}$ A ming és shi viszonya csupán annyiban tisztázható, amennyit a vonatkoztatás elárul róla. Ez a vonatkoztatás egy rendkívül fontos, a „vendég”, „vándor”, „úton lévő” értelmü, $k e$ 客 szó. A gondolat tartalmaz egy közvetett utalást is: Zhuangzi maga és vitapartnerei is ilyen „úton lévők”, kóbor vándorok, a valóság (shi) vendégei. A motisták ,vándor kardforgatóként”(you xia 遊俠) is éltek a 'köztudatban' szemben a konfuciánus ritualistákkal ( $r u$ 儒). Közvetlen utalása a mondásnak az a jelentése, mely a név és valóság nemreferáltathatóságára, össze-nem-egyeztethetőségére világít rá. ${ }^{208}$ Chad Hansen szerint ez összefüggésben lehet azzal, hogy a kínai nyelvelméletben nincs világosan megkülönböztetve a tény-állítás és az érték-állítás, egyben a deskriptív és preskiptív, normatív állítás. ${ }^{209}$

A szöveghely két gondolatot is felvet. Az egyik szerint a rend és a név nem kötődik olyan szorosan egymáshoz, mint az korábban a konfuciánusoknál - illetve majd később a legistáknál - szerepel, hiszen ők pontosan

\footnotetext{
203 Zhuangzi XVII.10; Tőkei 2005b: 104, Vasziljev 1977: 191.

204 ZhuangziXVII.11; Tőkei 2005b: 104.

${ }^{205}$ Zhuangzi II.2, 4; Tökei 2005b:64, 67, Várnai 2013: 465.

${ }^{206}$ Zhuangzi I.2; Tökei 2005b: 59.

207 Várnai 2013: 412.

208 Várnai 2011: 19-20.

209 Hansen 1991: 84-87.
} 
azért kívánták a neveket és a hozzájuk kapcsolódó kinevezéseket (ming 命) rendbetenni (zheng 正), hogy az égalattiban (tianxia) a rend és harmónia ( $l i$ yue 禮樂 - „szertartásrend és szertartási zene”) híven tükrözze az Ég Útja (tiandao) és az égalattiban levők eredeti viszonyát. A másik lehetséges értelmezés szerint Zhuangzi, mint taoista a szerepvállalást az égalatti kormányzásában, a hivatalviselést nem tartotta kívánatosnak, kiváltképp akkor nem, ha az amúgy is, spontán müködik, saját rendje'uralkodik' ${ }^{210}$ Ez drasztikus szakítás a konfuciánus értékrend és értékelmélet szemléletmódjával. ${ }^{211}$

A taoizmus tanítása szerint az „égalatti” civilizációja, és legfőbb fegyvere, a konfuciánus normáknak a szertartásrenden és erényeken keresztüli belenevelése az emberekbe, az eredeti, a daoból ,áradó” spontaneitás elvesztése. A bölcs, a shengren ezt 'szerzi vissza' a maga számára, olyan szellemi beállítódással, mely a „közönségesek ragyogásával” szemben a „tudatlanságot” választja. Ez a tudatlanság azonban valójában az ,igaz ember”, az eszményi zhenren valódi tudása, annak a tudása, aki a daoval összhangban él. Az alcímben feltett 'költői' kérdésre, miszerint kinek szánták a taoisták tanításukat, talán az a válasz, hogy semmiképpen nem „az embereknek”. Úgy tünik, ha lehetséges egyáltalán ilyet állítani az amúgy egyaránt elitárius tanítások esetén, közülük a taoista a legelitáriusabb az ókori kínai bölcselet történetében.

\section{Elsődleges források}

Arisztotelész 1992. „Metafizika Z.” (Ford. Steiger Kornél) Gond 1: 125-157.

Chan, Wing-tsit 1973. A Source Book in Chinese Philosophy. New Jersey: Princetown University Press.

Chen, E. M. 1989. The Tao Te Ching. (A New Translation with Commentary.) New York: Paragon House.

Duyvendak, Jan Julius L. 1954. Tao te ching. The Book of the Way and Its Virtue. London: John Murray.

Ivanhoe, Philip J. 2003. TheDaodejing of Laozi. Indianapolis: Hackett Classics.

ЯнХин-Шун 1950. ДревнекитайкийфилософЛао-изыиегоучение. Москва-Ленингад: Наука.

Jang, Ching-schun 1955. Der chinesische Philosoph Laudse und seine Lehre. Berlin: Deutscher Verlag für Wissenschaften.

Julien, Stanislas 1842. Lau Tseu Tao Te King. Le livre de la Voie et de la Vertue. Paris: A l'imprimerie Royale.

${ }^{210}$ Maspero 1978: 401, Allinson 1990: 53-54.

211 Várnai 2013: 410. 
Lau, Din Cheuk 1994. Lao-tzu: Tao Te Ching. New York: Alfred A. Knopf.

Legge, James [1891] 1971. The Texts of Taoism. [The Tao Teh King.] The Tao Te Ching of LaoTzu. [The Writings of Kwang-Ze] The Writings of Chuang Tzu Part I. Reprinted; New York: Dover Publ.

Li Tai-po, Tu Fu, Po Csü-ji versei 1976. Budapest: Európa Könyvkiadó.

Platón 1984a. Phaidon. Platón Összes Müvei I. (Ford. Kerényi Grácia) Budapest: Európa.

Platón 1984b. Theaitétosz. Platón Összes Müvei II. (Ford. Kerényi Grácia) Budapest: Európa.

Schwarz, Ernst (übersetz und herausgegeben) 1990. Laudse. Daudesching. Leipzig: Reclam.

Tőkei Ferenc 2005a; b; c. Kinai filozófia. Ókor. I.; II.; III. kötet. (Válogatta, fordította, a bevezetéseket, jegyzeteket készítette Tőkei Ferenc.) Budapest: Magiszter Társadalomtudományi Alapítvány.

Waley, Arthur 1958.The Way and Its Power. New York: Grove Press.

Wieger, Léon [1913] 2004. Les Pères du systéme taoïste. Nan-hoa-Tchenn-King. Oeuvre de Tchoang-Tzeu. Chicoutimi: Université du Québec.

Wilhelm, Richard 1940. DschuangDsi. Das Wahre Buch vom südlichen Blutenland. Leipzig: Druck der Spammer A. G.

Wilhelm, Richard 1994. Ji Csing. A Változások Könyve. A legösibb kínai bölcsesség. Budapest: Édesvíz Kiadó.

Wu Yi 1989. The Book of LaoTzu (Tao Te Ching). San Francisco: Great Learning Publishing Company.

\section{Felhasznált másodlagos szakirodalom}

Allan, Sarah \&Williams, Crispin 2000. The Guodian Laozi. Proceedings of the International Conference, Dartmouth College, May 1998. Berkeley: The Society for the Study of Early China-Institute of East Asian Studies, University of California.

Allinson, Robert E. 1990. Chuang-Tzu for Spiritual Transformation. Albany, NY: SUNY Press.

Bodde, Derk 1942. „Dominant Ideas in the Formation of Chinese Culture.”Journal of the American Oriental Society 62: 293-299.

Chan, Wing-Tsit 1963. The Way of Laotzu. New York: Macmillan.

Couvreur, Séraphin 1947. Dictionnaire classique de la langue chinoise. Peiping: Henri Vetch.

Feng Youlan [= Fung, Yu-lan] 1960. A History of Chinese Philosophy. Vol. 1. (Translated by Derk Bodde) New York: Macmillan.

Feng Youlan [= Fung, Yu-lan] 2003. A kínai filozófia rövid története. Budapest: Osiris Kiadó.

Feng Youlan [= Fung, Yu-lan] 1976. A Short History of Chinese Philosophy: A Systematic Account of Chinese Thought.(Ed.by Derk Bodde) New York: The Free Press. 
Gabelentz, Georg von [1881]1953. Chinesische Grammatik. [Leipzig.]. Reprint; Berlin: Deutscher Verlag der Wissenschaften.

Glasenapp, Helmuth von 1993. Az öt világvallás. Budapest: Gondolat.

Granet, Marcel 1934. La pensée chinoise. Paris: Albin Michel.

Hansen, Chad 1992. A Daoist Theory of Chinese Thought. Oxford: Oxford University Press.

Hansen, Chad 1991. „Language in the Heart-mind.” In: Robert E. Allinson (ed.) Understanding the Chinese Mind. The Philosophical Roots. Hong Kong - Oxford: Oxford University Press, 75-124.

Hansen, Chad 1981. „Linguistic Skepticism in the Lao-Tzu.” Philosophy East and West 31.3: 321-336.

Harbsmeier, Christoph 1998. Science and Civilisation in China. Vol.7, Part 1: Language and Logic. Cambridge-London: Cambridge University Press.

Harbsmeier, Christoph 1991. „Marginalia Sino-logica.” In: Robert E. Allinson (ed.) Understanding the Chinese Mind. The Philosophical Roots. Hong Kong - Oxford: Oxford University Press, 125-166.

Huang, Yen-kai 1964. A Dictionary Chinese Idiomatic Phrases. Hong-Kong: Eton Press.

Ivanhoe, Philip, J. 1993. „Zhuangzi on Skepticism, Skill, and the Ineffable Dao.” Journal of the American Academy of ReligionLXI.4: 639-654.

Kaltenmark, Max 1969. Lao Tzu and Taoism. Stanford, California: Stanford University Press.

Karlgren, Bernhard [1959] 1996. Grammata Serica Recensa. [Stockholm - Göteborg.] Taipei: SMC Publishing INC.

Karlgren, Bernhard 1962. Sound and Symbol in Chinese. Hong-Kong University Press - Oxford University Press.

Kósa Gábor 2008. „A létezők átváltozása. A pillangó motívuma a Zhuangziben.” Vallástudományi Szemle 2008.1: 91-106.

Kósa Gábor 2013a. „Laozi és a Daodejing.” In: Kósa Gábor - Várnai András (szerk.) Bölcselők az ókori Kínában. Budapest: Magyar Kína-kutatásért Alapítvány, 161-185.

Kósa, Gábor 2015. „'Trusting Words' in pre-Buddhist Chinese Texts.” In: Imre Hamar - Takami Inoue (eds.) Faith in Buddhism. Budapest: Budapest Center For Buddhist Studies, Eötvös Loránd University, 67-91.

Kósa Gábor 2013b. „Zhuangzi.” In: Kósa Gábor - Várnai András (szerk.) Bölcselők az ókori Kinában. Budapest: Magyar Kína-kutatásért Alapítvány, 186-211.

Liu, XiaoGan 1994. Classifying the Zhuangzi Chapters. AnnArbor: University of Michigan.

Maspero, Henri 1978. Az ókori Kina. Budapest: Gondolat.

Maspero, Henri 1971. Le taoïsme et le religions chinoises. Paris: Gallimard.

Moritz, Ralph 1990. Die Philosophie im alten China. Berlin: Deutscher Verlag der Wissenschaften.

Needham, Joseph 1984. „Az emberi törvény és a természeti törvények.” Filozófiai Figyelő VI.3: 79-100. [Needham, Joseph 1956. „Human Law and the Laws of Nature in China and the West." In: Needham, Joseph Science and Civilisation in China. Vol. 2. Cambridge: Cambridge University Press, 518-583.] 
Needham, Joseph 1960. Science and Civilisation in China. Vol. 2. Cambridge - London: Cambridge University Press.

Ощанин, ИляМихайлович 1959. Китайско-русский словарь. Москва: Госиздат.

Roberts, Moss 2001. Dao De Jing. The Book the Way. Berkeley-Los Angeles: Univ. of California Press.

Robinet, Isabelle 1987. Les Commentaires de Tao te king. Paris: Presses Universitaires de France.

Schuessler, Axel 1987. A Dictionary of Early Zhou Chinese. Honolulu: University of Hawaii Press.

Schuessler, Axel 2007. ABC Etymological Dictionary of Old Chinese. Honolulu: University of Hawaii Press.

Szojka Éva Szilvia 2007. „A Laozi filozófiájának főbb fogalmai.”ELPIS Filozófiai Folyóirat I.1: 114-133.

Takó Ferenc 2011. „A daozható dao.” In: Takó F. (szerk.) „Közel, s Távol”-az Eötvös Collegium Orientalisztika Mühely éves konferenciájának elöadásaiból, 2009-2010. Budapest: Eötvös Collegium, 191-202.

Várnai András 2013. „A kínai és a görög gondolkodás „összemérhetőségének” nehézségeiröl.” In: Kósa Gábor - Várnai András (szerk.) Bölcselők az ókori Kínában. Budapest: Magyar Kína-kutatásért Alapítvány, 382-494.

Várnai András 1984. „Az emberi törvény és a természeti törvények needhami felfogásáról."Filozófiai Figyelö VI.3: 101-107.

Várnai András 2010. „Az 'egyenes nevek' és a 'nemes ember' egyenessége. Konfuciánus nyelvértelmezés és értékelmélet." Távol-keleti Tanulmányok 2.2: 3-26.

Várnai András 2011. „Egyenes nevek” (Zheng ming). Nyelvelmélet, hatalomtechnika és erénytan a klasszikus kínai bölcseletben."Magyar Filozófiai Szemle 55.2: 9-31.

Vasziljev, Leonyid Sz. 1977. Kultuszok, vallások és hagyományok Kínában. Budapest: Gondolat.

Wieger, Léon [1915] 1965. Chinese Characters. Their origin, etymology, history, classification and signification. New York: Paragon Book Reprint Corp.

Wieger, Léon 1922. Histoire des croyances religieuses et des opinion philosophiques en Chine. Xien-Xien, Chine.

Wu, Joseph 1995. „Taoism.”In: Donald H. Bishop (ed.) Chinese Thought. An Introduction. Delhi: Motilal Banarsidass, 32-58. 